\title{
BUILDING BRAND TRUST BY CHOOSING THE RIGHT LOCATION: WHEN THE BUSINESS HEADQUARTERS SITE INFLUENCES CLIENTS' TRUST IN A BRAND
}

Christian Gomes-e-Souza Munaier University of Sao Paulo - USP. Sao Paulo, SP - Brazil. munaier@usp.br

Rodolfo Rodrigues Rocha University of Sao Paulo - USP. Sao Paulo, SP - Brazil. rodolfo.rocha@usp

Jerônimo Henrique Portes Mackenzie Presbyterian University - MPU. Sao Paulo, SP - Brazil. jeronimo.portes@bol.com.br

Objective: We investigate the influence of the business headquarters location of a services firm on clients' brand trust.

Method: An online survey was conducted with Les Mills brand's clients, resulting in 138 valid responses. Multivariate statistical techniques were used to analyze the data collected.

Main results: The clients' trust in a services brand with a single regional headquarters (HQ) in a country varies depending on the country's geographic region. Clients in the same state where the single regional HQ of a services firm is located trust more in the services brand than clients from other states in the same geographic region. Clients from geographic areas with open cultures show higher levels of general brand trust than clients from geographic regions with closed cultures.

Theoretical/methodological contribution: We contribute to branding literature by showing the influence of location on brand trust. As to location choice theory, we contribute by adding brand trust as one more consequence of such choice. Our main methodological contribution is Delgado-Ballester's brand trust scale (2004) validation in the context of services.

Relevance/originality: Findings related to location choice and brand trust have theoretical and practical implications. On the one hand, we put together two apparently unrelated concepts. On the other hand, we apply such concepts to a real-world context.

Managerial implications: By realizing that the location of a business HQ influences clients' brand trust, we argue that location choice is a complex process that companies should carefully manage.

Keywords: Location Choice. Brand Trust. Regional Differences.

\section{How to cite the article}

American Psychological Association (APA)

Munaier, C. G. e S., Rocha, R. R., \& Portes, J. H. (2022, Jan./Mar.). Building brand trust by choosing the right location: when the business headquarters site influences clients' trust in a brand. Brazilian Journal of Marketing, 21 (Special Issues), 88-108. https://doi.org/10.5585/remark.v21i1.20386. 


\section{Introduction}

Selecting a business location is not a trivial decision companies have to face as it involves a complex set of choices (Clouse et al., 2020). Economic costs (e.g., workforce, real estate, and energy) are the elementary issues companies consider when dealing with such a decision (Melo et al., 2009). However, non-economic elements play a significant role in business site selection decisions (Lunnan et al., 2019). Such features range from quality of life and housing - focusing on employees (Ebert \& Adam Jr, 1977), social and cultural factors characteristics of the city, state, and country (MacCarthy \& Atthirawong, 2003).

It is essential for cities, states, and countries to attract businesses (Anholt, 2010), as it involves long-term benefits that count in favor of the place's image (Clouse et al., 2019). Matching business interests and place characteristics is a challenging situation that can benefit both sides (Belderbos et al., 2017). A company's characteristics are shaped by the region or country culture in which it was founded (Khamitov et al., 2009). When it comes to multinational firms and brands, a company is also impacted by the regions and countries' cultures in which they set their regional headquarters (HQ) (Belderbos et al., 2017).

Assuming that different regions have distinct cultures implies recognizing that customers also have specific characteristics depending on where they live (Jayne, 2006). Customers' trust in a brand is one of the characteristics impacted by a culture that has been studied by consumer behavior researchers (Southworth, 2019). Brand trust is a critical aspect customers consider when evaluating alternatives in a buying decision process (Song et al., 2019). Thus, it is a central element for companies concerning branding and relationship marketing (Morgan \& Hunt, 1994). Whether a company provides consumer goods or services can also impact the congruence between the brand's and consumers' values (Kaufmann et al., 2016; Zhang \& Bloemer, 2008), making brand trust an even more dynamic ever-changing factor to be considered.

In the context of the services, the clients' evaluation of perceived risk is more significant when compared to the context of the consumer goods due to the high level of credence attributes involved (Shulga et al., 2021). In such situations, brand trust is seen as clients' expectations about intention and security messages promoted by the companies (Delgado-Ballester, 2004; Vivek, Beatty, \& Morgan, 2012). Thus, brand power becomes a competitive advantage for businesses worth investing money and effort (Abimbola, 2001; An et al., 2019; Foroudi, 2019).

Intercultural studies in consumer behavior usually involve distinct cultures (Chan et al., 2016), comparing western and eastern countries or contrasting poor and rich regions. We could 
not identify brand trust in the literature studies comparing such construct in different areas from the same country. In a continental country like Brazil, such cultural differences among regions are more complex and do not reflect the geographic segmentation used by marketers (Alfinito et al., 2019). Despite their importance, studies showing the impact of business location on client behavior are also fledgling in the literature (Belderbos et al., 2017). Finally, specific characteristics of the client-service brand relationship regarding brand trust need further investigation (Zhang \& Bloemer, 2008).

Aiming to bridge such gaps in the literature, the goals of this study are two-fold: first, we investigate the influence of business location on clients' brand trust. Such investigation is carried out by analyzing clients from a global services firm brand (Les Mills) with its subsidiary always located in São Paulo since the beginning of Brazilian operations and comparing different Brazilian regions. Our second goal is to verify the applicability of the goods brand trust scale, proposed by Delgado-Ballester (2004) and validated in the Brazilian context by Bastos et al. (2015) in the services brands context.

Thus, this study contributes to both the location choice literature and practice by discussing cultural aspects involved in such a context and revealing the consequences of this decision. This paper's results show a statistical difference in the customers' brand trust comparing the São Paulo state (where the regional firm's HQ is located) and different Brazilian regions (e.g., São Paulo itself is higher than the Southeast region without São Paulo). Also, we contribute to both the branding literature and practice by analyzing the brand trust concept in the services' context and showing the specificities of such an approach. This manuscript is organized as follows: at first, the theoretical framework and hypotheses are presented. Next, the methods and quantitatively treated results of a previously validated scale are presented. Finally, discussions of results, limitations, and suggestions for further research are presented.

\section{Theoretical background and hypotheses development}

\subsection{Social exchange theory and brand trust}

Since Homans (1958) proposed the concept of social exchanges (such as approval, trust, or prestige) as a human behavior comparable to commercial trades, where the individual seeks to gain mutually rewarding results in these exchanges, scholars have sought to analyze the possibilities of its application in varied fields. Such studies provided advances in the Social Exchange Theory (SET) literature (Cropanzano \& Mitchell, 2005). According to this proposal, SET can explain the cognitive process arising from cost/benefit analysis in social relations. 
During social interactions, the various social behaviors of individuals are types of commodities to be traded. If the individuals' gains are more significant than the cost of the interaction, they will continue to interact, versus when the cost is higher, the individual will cease the interaction (Zhao et al., 2017).

Trust is an intention, an attitude of seeing oneself in a vulnerable way to the other's actions that occurs when it is concluded that the other party has principles and values, gathers skills or abilities, and expresses a desire to do good for whose trusted (Barreto et al., 2015). In the light of SET, such characteristics, initially, attributes of human relationships, were carried over to commercial relationships and have been an intense area of research for Marketing (Abimbola, 2001; An et al., 2019; Delgado-Ballester, 2004; Foroudi, 2019; Kaufmann et al., 2016; Shulga et al., 2021; Song et al., 2019; Vivek et al., 2012; Zhang \& Bloemer, 2008).

Trust is one of the most powerful elements for a brand as it contributes to a longerlasting business relationship with the clients (Berry, 1995). Consistency, competence, honesty, responsibility, and cooperation are some of the characteristics that can reflect in consumers' trust in a brand, heading to enduring relationships (Baptista et al., 2011). By building trust and demonstrating commitment, a successful brand can create emotional bonds with its clients (D'Angelo et al., 2006). For services firms' brands, the interaction between the client and the employee providing the service also interferes and determines the client's trust in the brand (Guardani et al., 2013). After all, the company's benefits when the clients trust its brand are remarkable as the relationship goes beyond simple transactions (Ravald \& Grönroos, 1996). Brand trust can increase clients' loyalty and favor positive word-of-mouth (WOM) (Broeckelmann \& Groeppel-Klein 2008; O'Cass \& Carlson, 2012).

\subsection{Location choice and brand trust}

Consumer goods companies chose their factories and facilities locations based on easily measurable factors, including logistics costs, energy costs, and tax incentives (Clouse et al., 2020; Melo et al., 2009). For a services firm, location decisions involve factors that are less easy to measure or judge, such as availability of skilled labor, quality of life, and local culture (Clouse et al., 2020; Ebert \& Adam Jr, 1977). When it comes to the location choice of a regional headquarters (HQ), city connectivity is the most important characteristic a company looks for (Belderbos et al., 2017).

Building on the literature of country reputation, Mariutti (2017) shed light on the importance of managing reputation as a critical aspect for achieving sustainable prosperity. Bell 
(2016) reinforces such importance and goes further by proposing the connection between place reputation and corporate reputation to advance both fields of study. The literature on branding is shown to support theory and managerial practices on reputation (Bell, 2016; Mariutti, 2017), which reveals that brand trust is an element to be connected to reputation in its broad perspective.

Due to the characteristic of the inseparability of services, services brands have to deeply understand their clients' profiles (Moeller, 2010). Different geographic regions have different cultures; hence clients from distinct geographic areas carry specific characteristics, even if they live in the same country (Jayne, 2006). As brand trust is a critical aspect for both clients and brands (Song et al., 2019), services firms must evaluate the characteristics of clients from different geographical areas to understand their specificities (Kaufmann et al., 2016; Zhang \& Bloemer, 2008). The first step into this understanding is to check whether clients' brand trust varies depending on the geographic region. Thus, we propose the following:

$\mathbf{H}_{1 \mathbf{a}}$ : The clients' trust in a services brand with a single regional HQ in a country varies depending on the country's geographic region.

Values, beliefs, and a sense of belonging are elements present in the trust-building process between individuals themselves and between companies and consumers (Kegler \& Fossá, 2010; Michener et al., 2005). The congruence between clients' and brands' values is a determinant of brand trust (Kaufmann et al., 2016; Zhang \& Bloemer, 2008), posing a challenge for companies with a single HQ with its brands present in different regions.

Territory and territoriality are key geography concepts beyond physical space and domination (Rosendahl, 2005). The territorological perspective has acquired multiple applications in branding, from place branding to site selection (Warnaby, 2018). Regarding territoriality, there is a symbolic relation between culture and space, strengthened by the group's individuals and collective experiences concerning the place they live (Rosendahl, 2005). Such ties can even determine interpersonal trust (Inglehart, 1999).

Further, ethnocentrism is a sociological concept that consumer behavior literature adopted to compare consumers from different countries, but that also can be used to narrow comparisons (Fernández-Ferrín \& Bande-Vilela, 2013). Such a concept can be characterized as people's tendency to identify their group as superior to others, recognizing their groups as the center of the universe (Michener et al., 2005). In Brazil, local superiority demonstrations are 
also discussed in terms of parochialism or localism (de Sousa Júnior et al., 2019; Lopes, 2009). Thus, as the cultural characteristics of both a brand and a client reflect the specificities of the culture in which they are inserted (Khamitov et al., 2019), and that ethnocentrism makes clients have more trust in brands which are closer to their group (Shimp \& Sharma, 1987), we put forward that:

$\mathbf{H}_{1 \mathbf{b}}$ : Clients in the same state where the single regional HQ of a services firm is located trust more in the services brand than clients from other states in the same geographic region.

\subsection{Regional and cultural perspectives in brand trust}

Consumers from geographically distant countries with opposite cultures can show similar behaviors regarding trust in local brands. In 1987, Shimp and Sharma's study indicated that American consumers trust more American brands than other countries. Siemieniako et al. (2011) got similar results in a completely different context. A regional level analysis found that Polish consumers prefer brands from their regions because they feel morally obligated to consume local brands.

In the Brazilian context, several studies point to the opposite trend; consumers prefer and trust brands from other countries than brands from Brazil (Klein et al., 2006). However, in a narrower perspective, consumers from the city of São Paulo are shown to have more ethnocentric behaviors regarding brands than consumers from other Brazilian states' capitals (Strehlau et al., 2012). Regarding trust in general, a number of studies in the Brazilian context indicate a strong presence of parochialism or localism in some states such as São Paulo (Velloso, 1993), Pernambuco, and Rio Grande do Sul (de Sousa Júnior et al., 2019). Such findings suggest that these states have a more closed culture. São Paulo is also part of the region where consumers trust less in firms and brands in general, i.e., the Southeast (ACSP, 2018).

While regionalism evokes feelings that reinforce broad social and cultural bonds, parochialism or localism are ideas that will strengthen specific local characteristics (Freyre, 1996). Thus, it is possible to suggest that brand trust is closer to local characteristics than broader social and cultural aspects. Such a categorization is reinforced if we oppose findings from ACSP (2018) showing that consumers from the Brazilian Northeast region have high levels of general trust and the results delivered by de Sousa Júnior et al. (2019), indicating that Pernambuco (a state from the Northeast region) has characteristics of parochialism or localism. Consequently, we propose that: 
$\mathbf{H}_{2}$ : Clients from geographic regions with open cultures show higher levels of general brand trust than clients from geographic regions with closed cultures.

\section{Method}

Before hypotheses testing, the Delgado-Ballester's brand trust scale (2004) applicability was verified, validated in the Brazilian context by Bastos et al. (2015), now in the context of services. Several trust characteristics are present in different scales proposed to measure consumers' brand trust (e.g., Delgado-Ballester, 2004; Hernandez \& Mazzon, 2005; Li, 2008). Delgado-Ballester (2004) proposed a brand trust scale consisting of eight variables to measure consumers' trust in a Spanish consumer goods brand. This scale was adapted to the Brazilian context by Bastos et al. (2015) to observe consumers' trust in a steel mill brand. Hernandez and Mazzon (2005) proposed a scale in which trust is recognized as a multidimensional construct enclosing the following six dimensions: dispositional trust, calculative-based trust, institutional-based trust, knowledge-based trust, characteristics-based trust, and the "grammar" of trust. It is possible to identify a deep synergy by analyzing both scales since the trust dimensions proposed by Hernandez and Mazzon (2005) are also present in Delgado-Ballester's (2004) scale items.

\subsection{Scale}

The present work is part of the model of Delgado-Ballester (2004) and Bastos et al. (2015) to propose the same scale, however, applying it in another context and segment. A 7point Likert scale was used in the present manuscript, where 1 was "totally disagree" and 7 was "totally agree" with the questionnaire's statements. The adjustments were made to its application - replacing the steel company "Alpha" with a service provider company, "Les Mills". The scale reliability's results (Cronbach's $\alpha=0.9$ ), composite reliability (0.89), average variance extracted $(\mathrm{AVE}=0.5)$, standard deviation, collinearity analysis, loading weights, and T-statistics can be observed in the Results section (Table 2) and that were adequately validated (Hair, Jr. et al., 2009).

\subsection{Sample selection}

Les Mills (www.lesmills.com) is a New Zealand-based company present in more than 100 countries, offering technical group fitness training programs to thousands of entrepreneurs 
and instructors of the Fitness Business industry. For the gyms and health clubs to provide their final clients with one of the Les Mills programs, entrepreneurs and instructors must be licensed and trained attending one or two-days Les Mills workshops. The license fees are monthly (gyms) or quarterly (instructors), and no payment results in the instructor/firm's loss of license and impediment to continuing using the licensor services.

The nature of the service offered by Les Mills was why we chose this brand: continually delivered business services, where the service is provided to the customer repeatedly throughout the contract (Briggs et al., 2016; Munaier \& da Costa, 2021). We understand that this is a relationship where the respondent can measure all items on the brand trust scale.

From 1997 to the current time (June 2021), the company maintained its physical headquarters (HQ) in São Paulo/SP. Its address is well known because, in numerous opportunities, licensed clients from all over Brazil go to the company's HQ for workshops and meetings.

It is worth reiterating that all the respondents validated in this manuscript were active brand customers at the time of collection. Respondents were selected who answered a filter question that was decisive for their sequence or not to the proposed survey: are you a Les Mills licensed gym owner and/or a Les Mills licensed instructor? The respondent who answered "no" in the survey did not proceed to the next session and was excluded. One hundred forty-four complete questionnaires were completed. Following the Bastos et al. (2015) footsteps, outliers' presence was verified, performing the Mahalanobis distance calculation. The 138 validated questionnaire results can be observed in the fourth session.

\subsection{Data collection}

The data collection took place online via a direct link to the questionnaire hosted on the Google Forms platform through Les Mills' customer database. "Online platforms have provided convenient access for samples of businesses and consumers, which were once difficult, expensive, and often impossible to obtain" (Hair et al., 2018, p. 689).

We obtained 144 respondents who fulfill the requirements of being Les Mills's current clients. Six were removed from the analysis because they were categorized as outliers, leaving 138 validated respondents. Of the respondents, $55.8 \%$ were male, $76.8 \%$ identified themselves as licensed instructors, and 23.2\% were Licensed Gyms Owners. 66\% of the respondents are between 24 and 37 years old, $81.9 \%$ undergraduate or higher, and $41.3 \%$ are in the state of São Paulo, where Les Mills' Brazilian HQ is located. 
3.4 Data analysis procedure

Descriptive data analysis, exploratory factor analysis (EFA), and confirmatory factor analysis (CFA) of the scale items were performed. EFA was performed using the principal components method with Varimax rotation. Both IBM SPSS v.22 and SmartPLS v.2.0 software were used. We tried to verify the Cronbach's alpha ( $\alpha \geq 0.7)$, the average variance extracted $(\mathrm{AVE} \geq 0.5)$, and the composite reliability $(\mathrm{CC} \geq 0.7)$ as minimum assumptions for its acceptability (Hair Jr. et al., 2009). In addition, the Bartlett sphericity test ( $p<0.001)$ and the Kaiser-Meyer-Olkin (KMO) test.

The hypotheses, theoretical references sustaining them, the multivariate techniques used to validate them, and the expected results can be observed in Figure 1.

\section{Figure 1}

Methodological Association Matrix

\begin{tabular}{|c|c|c|c|c|c|}
\hline $\begin{array}{l}\text { Theoretical } \\
\text { Framework }\end{array}$ & Research Goals & $\bar{H}$ & Items & $\begin{array}{c}\text { Analysis } \\
\text { Techniques }\end{array}$ & Expected search results \\
\hline $\begin{array}{l}\text { (Bastos et al., } \\
\text { 2015; } \\
\text { Delgado- } \\
\text { Ballester, } \\
\text { 2004; Hair, Jr. } \\
\text { et al., 2009) }\end{array}$ & $\begin{array}{l}\text { Analyze whether the } \\
\text { initially proposed } \\
\text { scale for goods is } \\
\text { statistically validated } \\
\text { for services }\end{array}$ & & Q1-Q8 & $\begin{array}{l}\text { Exploratory } \\
\text { Factorial, } \\
\text { Confirmatory } \\
\text { Factorial }\end{array}$ & $\begin{array}{l}\text { It is expected that } \\
\text { Delgado-Ballester's trust } \\
\text { scale be appropriated to } \\
\text { measure trust on a service } \\
\text { brand }\end{array}$ \\
\hline $\begin{array}{l}\text { (Belderbos } \text { et } \\
\text { al., 2017; Hair, } \\
\text { Jr. et al., 2009; } \\
\text { Lunnan } \text { et al., } \\
\text { 2019) }\end{array}$ & $\begin{array}{l}\text { Analyze whether } \\
\text { there are differences } \\
\text { between the brand } \\
\text { trust scale means } \\
\text { concerning the } \\
\text { respondents' regions }\end{array}$ & $\begin{array}{l}\mathrm{H}_{1 \mathrm{a}} \\
\mathrm{H}_{1 \mathrm{~b}} \\
\mathrm{H}_{2}\end{array}$ & & $\begin{array}{l}\text { ANOVA } \\
\text { with LSD } \\
\text { post-hoc } \\
\text { analyzes }\end{array}$ & $\begin{array}{l}\text { It is expected that } \\
\text { techniques used show } \\
\text { that there are trust's mean } \\
\text { differences between } \\
\text { regions, validating all } \\
\text { hypotheses }\end{array}$ \\
\hline
\end{tabular}

Source: Prepared by the authors from Mazzon (2018).

\section{Results}

To better understand the distribution of respondents and observe whether Les Mills' brand trust has a different response depending on the individual's region, we created a categorization as shown in Table 1 . Respondents from the Northeast $(\mathrm{NE}, \mathrm{n}=30$ ) were classified as group 1. Respondents from São Paulo itself (SP, $n=57)$ were classified as group 2. Respondents from Southeast states without SP (SE-SP, $n=34)$ were classified as group 3, 
and respondents from South $(\mathrm{S}, \mathrm{n}=17)$ were classified as group 4. Respondents from Brazilian North and Midwest regions were not used in this manuscript.

Table 1

Distribution of Respondents by groups

\begin{tabular}{llll}
\hline \hline Group & Region & Frequency & Percent \\
\hline Group 1 & NE & 30 & $26,5 \%$ \\
Group 2 & SP & 57 & $38,8 \%$ \\
Group 3 & SE-SP & 34 & $23,1 \%$ \\
Group 4 & S & 17 & $11,6 \%$ \\
\hline & Total & $\mathbf{1 3 8}$ & $\mathbf{1 0 0 \%}$
\end{tabular}

$\overline{\text { Source: Prepared by the authors from the data collection }}$

The respondents from São Paulo were separated from the other Brazilian Southeast states to observe better their attitude, since, as mentioned above, the Brazilian Les Mills' administrative headquarters (HQ) is in São Paulo/SP. It is possible to observe that almost onethird of the respondents are from the state where the company's HQ is located in Brazil.

The means, standard deviations, collinearity analysis, loading weights, and T-statistics from the 138 respondents can be seen in Table 2 and the validity analyses of the brand trust scale. 


\section{Table 2}

Statistical Analyses

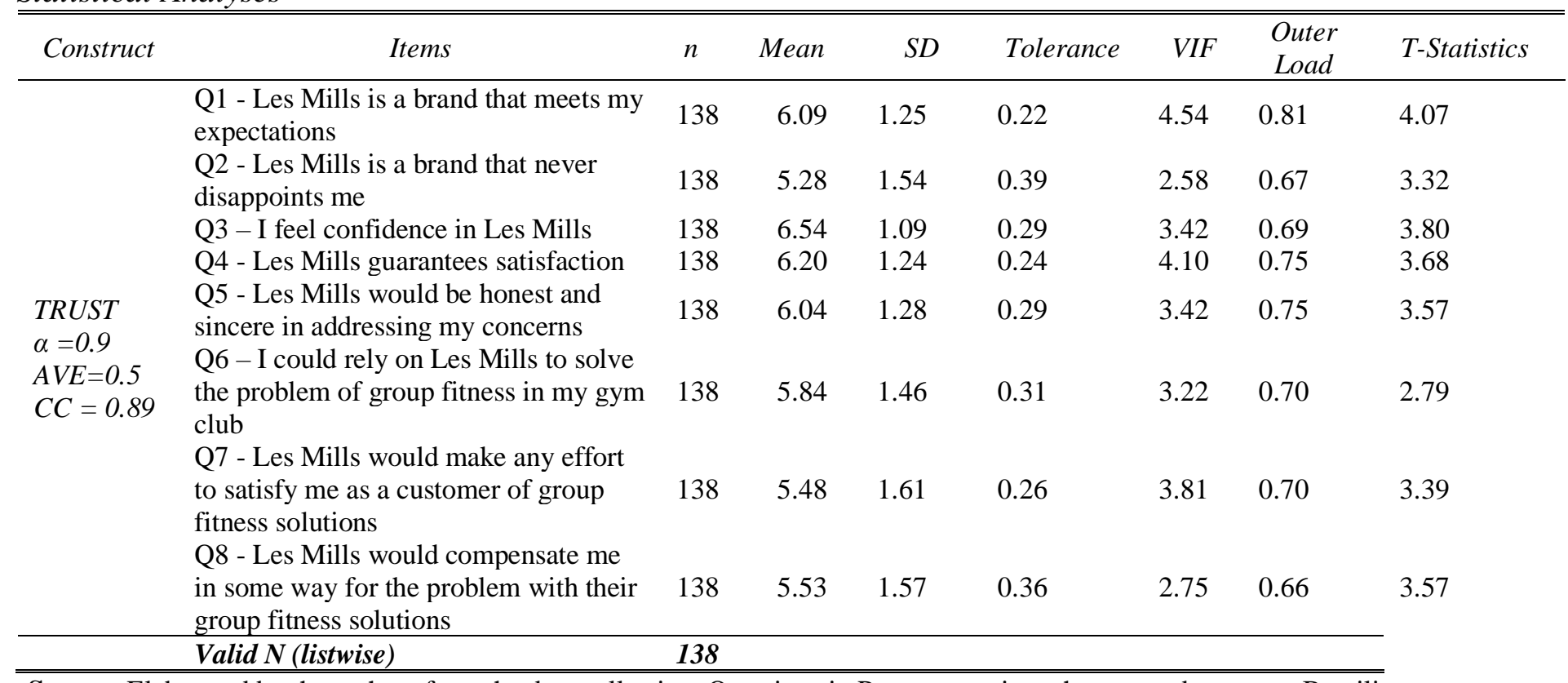

Source: Elaborated by the authors from the data collection. Questions in Portuguese since the respondents were Brazilian native (Portuguese native speakers). The original scale, in English, can be observed in Delgado-Ballester (2004).

As shown in Table 2, the eight variables formed a construct validated by the premises of reliability analyses (Hair et al., 2009). Cronbach's Alpha $=0.9, \mathrm{AVE}=0.5$ and Composite Reliability $=0.89$. The variables passed the multicollinearity criterion, all having a VIF lower than 10. Its external loads and the T-statistic of each indicator also confirm the quality of the scale.

An Exploratory Factor Analysis was performed. The Bartlett sphericity test was significant $(\mathrm{p}<0.00)$, and the Kaiser-Meyer-Olkin test $(\mathrm{KMO})$ was adequate $(0.908)$ for the analysis (Hair, Jr. et al., 2009). $71.6 \%$ of all variances were explained in a single main component, reinforcing the scale's consistency and reliability and validating it for the following analyses. The mean of the eight variables used in the 7-points Likert scale generated a new variable, "TRUST" $\left(\mathrm{M}_{\mathrm{TRUST}}=5.87 ; \mathrm{SD}=1.17\right)$. Thenceforward, all analyses were carried out to analyze whether there is a difference in services brand trust depending on the region where the service provider and the customer are located.

An ANOVA was performed with this manuscript's four groups observed, seeking to identify statistically significant differences between means of brand trust in the groups.

Among the ANOVA's assumptions is the samples' homogeneity. When observing the results of the 138 respondents, it is possible to identify the homogeneity (Levene-test, sig = 
0.158). Hair et al. (2009) recommended that "in small samples of 50 or fewer observations, and especially if the sample size is less than 30 , significant deviations from normality can have a substantial impact on the results" (p. 83). As our sample is greater than 30, it is not necessary for the present analysis normality distribution. The Levene-test, demonstrating the samples' homogeneity, offers the necessary condition to the following analysis.

The ANOVA results in a statistically significant difference between brand trust and regions: $\mathrm{F}_{\text {TRUST }}(3,134)=3.924 ; \mathrm{p}=0.01$. This result confirms $\mathbf{H}_{1 \mathbf{a}}$ that the clients' trust in a services brand with a single regional HQ in a country varies depending on the country's geographic region

To analyze hypotheses $\mathrm{H}_{1 \mathrm{~b}}$ and $\mathrm{H}_{2}$, an LSD post-hoc test was performed to identify the differences in the region groups' brand trust mean. The LSD post-hoc test is observed in Table 3. It is noted that there is no statistical difference between the means of Brazilian's NE region and SP State itself ( $\operatorname{sig}=1)$, as well as there is no difference between Brazilians' regions SE (without SP) and S (sig = 0.776). However, there are differences between NE and SP to SE-SP and S.

Table 3

LSD Post-Hoc Test: Trust Brand and Brazilian Regions

\begin{tabular}{llll|lll}
\hline & & \multicolumn{2}{c}{ Mean } & \multicolumn{2}{c}{ 95\% Confidence Interval } \\
\cline { 6 - 7 } (I) REGION & $(\mathrm{J})$ REGION & Difference (I-J) & Std. Error & \multicolumn{2}{c}{ Sig. } & \multicolumn{2}{c}{ Lower Bound } & Upper Bound \\
\hline NE & SP & .00000 & .25487 & 1.000 & -.5041 & .5041 \\
& SE-SP & $.71324^{*}$ & .28304 & .013 & .1534 & 1.2730 \\
& S & .61765 & .34303 & .074 & -.0608 & 1.2961 \\
\hline SP & NE & .00000 & .25487 & 1.000 & -.5041 & .5041 \\
& SE-SP & $.71324^{*}$ & .24485 & .004 & .2290 & 1.1975 \\
& S & $.61765^{*}$ & .31226 & .050 & .0000 & 1.2352 \\
\hline SE-SP & NE & $-.71324^{*}$ & .28304 & .013 & -1.2730 & -.1534 \\
& SP & $-.71324^{*}$ & .24485 & .004 & -1.1975 & -.2290 \\
& S & -.09559 & .33565 & .776 & -.7594 & .5683 \\
\hline S & NE & -.61765 & .34303 & .074 & -1.2961 & .0608 \\
& SP & $-.61765^{*}$ & .31226 & .050 & -1.2352 & .0000 \\
& SE-SP & .09559 & .33565 & .776 & -.5683 & .7594 \\
\hline \hline
\end{tabular}

*. The mean difference is significant at the 0.05 level.

Source: Elaborated by the authors from the data collection using the IBM SPSS software.

It is worth remembering that São Paulo is the state where the Brazilian HQ of the company focused is located and that, as observed in the post-hoc test, the customers' trust's mean achieved is best and statistically different from others Southeasters states (SE-SP, sig = 
0.004). This result confirms that clients in the same state where a services firm's single regional HQ trusts more in the services brand than clients from other states in the same geographic region, validating $\mathbf{H}_{\mathbf{1 b}}$.

As supported in this article, there are cultures more open to trusting than others. In Brazil, with its continental dimensions, such cultural differences are also observed. Brazilian's NE region, a most trust-open region, presents the highest average, in antagonism to SE (without SP, sig $=0.013$ ), a region recognized as more conservative. This result supports $\mathbf{H}_{2}$ that clients from geographic regions with open cultures show higher levels of general brand trust than clients from geographic regions with closed cultures. Moreover, customers from São Paulo, who were initially expected to behave less openly, such as other Southeast and South customers, have a likely northeaster's trust behavior. A graphic representation is observed in Figure 2.

\section{Figure 2}

Four Groups and Brand Trust Graphic.

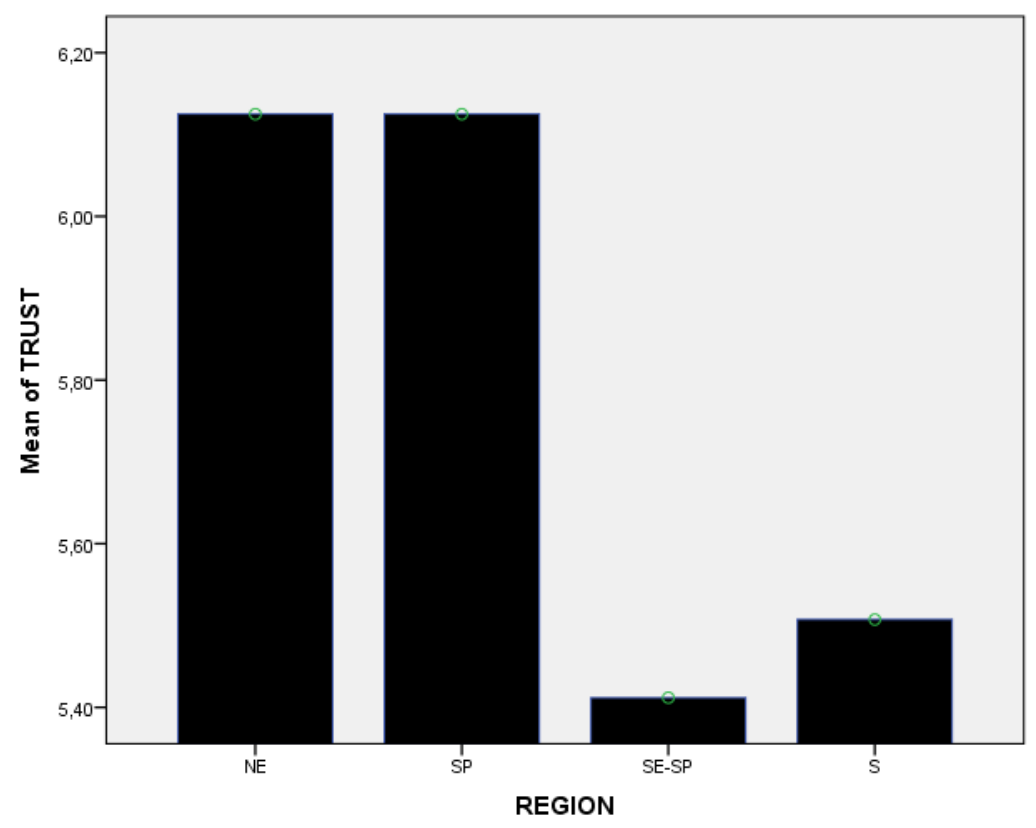

Source: Elaborated by the authors using the IBM SPSS software.

\section{Conclusions}

Our findings align with the literature on trust and regionalism concerning differences in trust in Brazilian regions. As identified by ACSP (2018), our results point to the Southeast and South Brazilian regions as those with less brand trust when compared, for example, with the northeast. The congruent values, ties, and sense of belonging between consumers and brands 
(Inglehart, 1999; Kaufmann et al., 2016; Kegler \& Fossá, 2010; Michener et al., 2005; Zhang $\&$ Bloemer, 2008) are also revealed in our study as a challenge for companies, especially for those with a single headquarters (HQ) with their brands present in different regions.

In light of the social exchanges theory (SET), trust is a human attribute incorporated by companies' marketing in their strategies to gain customer loyalty and engagement (Kandampully et al., 2015; Vivek et al., 2014). From this perspective, this article sought to observe the trust in the service brand and the differences in brand trust in three Brazilian regions: Northeast, Southeast, and South. In doing so, we sought to assess the difference between the service brand trust among its customers and the importance of the brand properly choosing its headquarters location. After all, if trust is a fundamental attribute to achieve customer loyalty, and the company's characteristics are shaped by the region or country culture in which it was founded or which a multinational set its regional HQ (Belderbos et al., 2017; Khamitov et al., 2009; Lunnan et al., 2019), this article contribute both to literature and managerial implications.

Previous studies have contributed to trust in loyalty relationships (Cropanzano \& Mitchell, 2005; Homans, 1958; O'Cass \& Carlson, 2012). Trust allows customers to lower their defense and take more significant risks in their decision-making process (Barreto et al., 2015). Thus, this study advances in the literature on brand trust and regionalism. The results obtained through the survey and 138 customers of a service brand show a statistically significant difference in consumer trust in three Brazilian regions. In this sense, as previously identified by ACSP (2018), the southeast region is the most brand distrustful, regarding the south and northeast (the one that trusts the most).

However, analyzing the customer trust averages in the state of São Paulo, the means are higher than the other southeastern states' averages, with statistically significant differences. Moreover, their trust averages are almost as high as those in the northeast region, with no statistical differences. The HQ of the observed company is in São Paulo. Thus, this article proposes an important literature addition regarding the impact of the location where the service brand places its HQ. It is possible to affirm that the service brand's headquarters location enhances the trust relationship of consumers in that micro-region. In addition to having statistical support for this statement, there is also theoretical support, as the geographic proximity and openness to resolve doubts and discontents arising from bad experiences, which the nearby HQ offers, increase the consumer's sense of security. Security is one of the central elements of trust. 
Furthermore, the Delgado-Ballester (2004) scale proved to be adequate to measure brand trust also in services, being possible to analyze the attitude of the B2B consumer in its eight variables in a statistically consistent way.

Finally, by realizing that the location of a business HQ influences clients' brand trust, we argue that location choice is a complex process that companies should carefully manage. Brand trust is one more non-economic element that should play a significant role in business site selection decisions. Our findings are focused on a regional HQ of one service's multinational brand. However, as brand trust was shown to be strongly influenced by HQ location, we expect that the impact of location choices on brand trust in other contexts would replicate our results.

\subsection{Managerial implications}

First, it is essential to pay tribute to the analyzed brand. With an average above 5 on a 7-point Likert scale in brand trust, a surveyed company has a high trust index $\left(\mathrm{M}_{\mathrm{TRUST}}=5.87\right.$; $\mathrm{SD}=1.17)$. This result can be observed at different intensities in the four groups studied, but in all of them, with performance considered adequate.

One of this article's contributions to managerial decisions focuses on the client's needs perspective, clearly in Brazil: the feeling of proximity that the service brand needs to arouse in its customer. Although the decision of its regional HQ is taken into account several elements, from the strategic to the entrepreneurs' personal ones, this article identifies that proximity can bring results in terms of trust contrary to what would be expected in a given region. Thus, having representatives or outposts in different country regions can increase the customer's relationship of trust with the brand. It will be worth identifying whether, in that particular region, there are professionals with the necessary skills to represent the brand. If such professionals are identified and hired, having them representing the company's values and culture in that region can give local customers a feeling of more closeness, that "there is one of us" in the company to mediate the demands of local customers.

Another practical contribution of this article is validating the scale to analyze trust in service brands, which can be used by services firms' brand managers, expanding their research tools. With only eight variables, companies will verify the degree of trust of their customers and analyze it in absolute numbers and a regionalized manner, regardless of their coverage area. It is possible to assess brand trust in regional terms if national, as done in this survey. Whether 
statewide or even municipal in scope, the brand will evaluate the customers' trust across microregions and seek to interfere and enhance each of these areas.

If the company's HQ determines a local advantage in building trust in the brand, the strategies to increase and expand it are in the hands of its managers. Such practices have the potential to positively influence companies' reputations, as flagged by Bell (2016) and Mariutti (2017).

\subsection{Limitations and suggestions for future research}

This research limitation begins with the support theory, which is still far short of what is needed to immerse more appropriately in the subject. Hence, also, the importance of this article to advance in theory. Another limitation was the sample size. Despite comprising the ten respondents per item, the ideal would be to have a balanced sample of the Brazilian five regions, which is a limitation and a suggestion for further research. In addition to surveying the states, whether the respondent is from the state capital or the interior could be analyzed, and there may be differences between them.

As brand trust is not only perceived by clients, but by multiple types of stakeholders, location choices could be further analyzed in clusters of inter-organizational networks (Cunha, Passador \& Passador, 2011). Such an approach would deepen the understanding of the impacts of location choice on brand trust. Further, regional and urban networks (Beck \& Storopoli, 2021) are also potential lenses to be explored by future research.

Another suggestion for further research in this regard is to analyze competing scales, using this one and Hernandez and Mazzon (2005), for example, to verify differences and similarities in the results. Also, one could check control, mediation, or moderation variables, such as time as a customer. Thus, mediation and moderation techniques could be applied.

Finally, it is also worth mentioning the punctual nature of consumer trust, since consumer trust is a thermometer of the moment, which can be changed in light of economic, political, social, and technological changes. Thus, it could be considered another article's limitation and a suggestion for future (and constant) research for its update. 


\section{References}

Abimbola, T. (2001). Branding as a Competitive Strategy for Demand Management in SMEs. Journal of Research in Marketing and Entrepreneurship, 3(2), 97-106. https://doi.org/10.1108/14715200180001480

ACSP - Associação Comercial de São Paulo. (2018). Índice Nacional de Confiança do Consumidor. Recuperado de http://mkt.acspservicos.com.br/digital/imprensa/ACSP_INC_Onda161_agosto2018.pdf. Acesso em 14 de março de 2021.

Alfinito, S., Assumpção, M., Torres, C. V., \& de Aragão, B. S. (2019). Is geographic segmentation suitable for marketing studies? An investigation applied to Brazil. Revista Brasileira de Marketing, 18(2), 243-267. https://doi.org/10.5585/remark.v18i2.3882

An, J., Ngo, L. V., Chylinski, M., \& Tran, Q. (2019). Customer advocates with a generous heart. Journal of Services Marketing, 33(2), 192-205. https://doi.org/10.1108/JSM-04-20180120

Anholt, S. (2010). Definitions of place branding-working towards a resolution. Place Branding and Public Diplomacy, 6(1), 1-10. https://doi.org/10.1057/pb.2010.3

Baptista, P. de P., Silva, W. V. da, \& Goss, L. P. (2011). Qualidade percebida e seus impactos sobre a satisfação, confiança e lealdade: um estudo com varejistas eletrônicos de serviços de download gratuito. Revista de Ciências Da Administração, 249-277. https://doi.org/10.5007/2175-8077.2011v13n30p249

Barreto, I. F., Crescitelli, E., \& Figueiredo, J. C. B. (2015). Relationship Marketing results: proposition of a cognitive mapping model. Revista Brasileira de Gestao de Negocios, 17(58), 1371-1389. https://doi.org/10.7819/rbgn.v17i58.2692

Bastos, D. H., Moura, L. R. C., \& Christino, J. M. M. (2015). Mensuração, teste e validação da confiança na marca. Revista Capital Científico - Eletrônica, 13(2). https://doi.org/10.5935/2177-4153.20150010

Beck, D., \& Storopoli, J. (2021). Cities through the lens of Stakeholder Theory: A literature review. Cities, 118, 103377. https://doi.org/10.1016/j.cities.2021.103377

Belderbos, R., Du, H. S., \& Goerzen, A. (2017). Global Cities, Connectivity, and the Location Choice of MNC Regional Headquarters. Journal of Management Studies, 54(8), 1271-1302. https://doi.org/10.1111/joms.12290

Bell, F. (2016). Looking beyond place branding: the emergence of place reputation. Journal of Place Management and Development, 9(3), 247-254. https://doi.org/10.1108/JPMD-082016-0055

Berry, L. L. (1995). Relationship marketing of services - growing interest, emerging perspectives. Journal of the Academy of marketing science, 23(4), 236-245 
Bochenek, M., \& Pomaskow, J. (2014). The use of the brand to build a competitive advantage of contemporary companies. Ekonomia i Prawo. Economics and Law, 13(2), 285-296.

Briggs, E., Landry, T. D., \& Daugherty, P. J. (2016). A framework of satisfaction for continually delivered business services. Journal of Business and Industrial Marketing, 31(1), 112-122. https://doi.org/10.1108/JBIM-06-2014-0125

Broeckelmann, P., \& Groeppel-Klein, A. (2008). Usage of mobile price comparison sites at the point of sale and its influence on consumers' shopping behaviour. The International Review of Retail, Distribution and Consumer Research, 18(2), 149-166.

Chan, F. F. Y., Petrovici, D., \& Lowe, B. (2016). Antecedents of product placement effectiveness across cultures. International Marketing Review, 33(1), 5-24. https://doi.org/10.1108/IMR-07-2014-0249

Clouse, C., Dixit, A., \& Turken, N. (2020). The role of place image for business site selection: a research framework, propositions, and a case study. Place Branding and Public Diplomacy, 16(2), 174-186. https://doi.org/10.1057/s41254-019-00144-4

Cropanzano, R., \& Mitchell, M. S. (2005). Social Exchange Theory: An Interdisciplinary Review. Journal of Management, 31(6), 874-900. https://doi.org/10.1177/0149206305279602

Cunha, J. A. C. D., Passador, J. L., \& Passador, C. S. (2011). Recomendações e apontamentos para categorizações em pesquisas sobre redes interorganizacionais. Cadernos EBAPE.BR, 9, 505-529. https://doi.org/10.1590/S1679-39512011000600005

D'Angelo, A. C., Schneider, H., \& Laran, J. A. (2006). Marketing de relacionamento junto a consumidores finais: um estudo exploratório com grandes empresas brasileiras. Revista de Administração Contemporânea, 10(1), 73-93.

Delgado-Ballester, E. (2004). Applicability of a brand trust scale across product categories. European Journal of Marketing, 38(5/6), 573-592. https://doi.org/10.1108/03090560410529222

de Sousa Júnior, J. H., Santos, W. S., \& da Rocha, R. A. (2019). A influência do bairrismo no comportamento de consumo em Pernambuco e no Rio Grande do Sul. $13^{\circ}$ Congresso Latino-Americano de Varejo e Consumo.

Ebert, R. J., \& Adam Jr, E. E. (1977). The Human Factor in Facilities Location Planning. Business Horizons, 20(6), 35-42.

Fernández-Ferrín, P., \& Bande-Vilela, B. (2013). Regional ethnocentrism: Antecedents, consequences, and moderating effects. Food Quality and Preference, 30(2), 299-308. https://doi.org/10.1016/j.foodqual.2013.06.011

Flores Filho, E. G. J., \& Ribeiro, R. C. (2012). Racionalidade limitada do consumidor e assimetria de informação. Economic Analysis of Law Review, 3(1), 109-121. 
Foroudi, P. (2019). Influence of brand signature, brand awareness, brand attitude, brand reputation on hotel industry's brand performance. International Journal of Hospitality Management, 76(May 2018), 271-285. https://doi.org/10.1016/j.ijhm.2018.05.016

Freyre, G. (1996). Manifesto regionalista. In FUNDAJ (7a). Ed. Massangana.

Guardani, F., Teixeira, M. L. M., Bido, D. D. S., \& Mazzon, J. A. (2013). The relationship between values, organizational practices and customers trust in the services sector. Production, 23(4), 806-817

Hair, Jr., J. F. H., Black, W. C., Babin, B. J., Anderson, R. E., \& Tatham, R. L. (2009). Análise Multivariada de Dados (6 ed). Artmed.

Hair, J. F., Harrison, D. E., \& Risher, J. J. (2018). Marketing research in the 21st century: Opportunities and challenges. In Revista Brasileira de Marketing (Vol. 17, Issue 5). https://doi.org/10.5585/bjm.v17i5.4173

Hernandez, J., \& Mazzon, J. (2005). Trust development in e-commerce and store choice: model and intial test. ENANPAD 2005. Encontro Nacional de Pós-graduação em Administração, Brasília.

Homans, G. C. (1958). Social Behavior as Exchange. American Journal of Sociology, 63(6), 597-606. https://www.jstor.org/stable/2772990

Inglehart, R. (1999). Trust, well-being and democracy. Democracy and trust, 88, 88-120.

Kahneman, D., \& Tversky, A. (1979). Prospect theory: An analysis of decision under risk. Econometrica: Journal of the Econometric Society, 47(2), 263-292.

Kaufmann, H. R., Loureiro, S. M. C., \& Manarioti, A. (2016). Exploring behavioural branding, brand love and brand co-creation. Journal of Product and Brand Management, 25(6), 516-526. https://doi.org/10.1108/JPBM-06-2015-0919

Kegler, B., \& Fossá, M. I. T. (2010). “ORGULHO GAÚCHO”: DE ELEMENTO IDENTITÁRIO REGIONAL À ESTRATÉGIA PUBLICITÁRIA. Razón y Palabra, 15(74), $1-26$.

Khamitov, M., Wang, X. (Shane), \& Thomson, M. (2009). ACRoss space and time: How cultural and institutional differences explain consumer-brand relationships' differential effects on brand loyalty. AP - Asia-Pacific Advances in Consumer Research, 36, 11-12. http://www.acrwebsite.org/volumes/1700304/volumes/ap12/AP-12 [copyright]

Lopes, R. H. (2009). "Cada brasileiro receba a parcella do insulto que lhe cabe": Regionalismo, separatismo e bairrismo no processo de mobilização cearense durante a Guerra de 1932. Revista Especialidades, 2(1), 1-18.

Lunnan, R., Tomassen, S., Andersson, U., \& Benito, G. R. G. (2019). Dealing with headquarters in the multinational corporation: a subsidiary perspective on organizing costs. Journal of Organization Design, 8(1). https://doi.org/10.1186/s41469-019-0052-y 
MacCarthy, B. L., \& Atthirawong, W. (2003). Factors affecting location decisions in international operations - A Delphi study. International Journal of Operations and Production Management, 23(7-8), 794-818. https://doi.org/10.1108/01443570310481568

Mariutti, F. G. (2017). The placement of country reputation towards place management. Journal of Place Management and Development, 10(3), 240-253. https://doi.org/10.1108/JPMD-10-2016-0067

Mazzon, J. A. (2018). Uso da matriz de Amarração Metodológica em Marketing. Brazilian Journal of Marketing - BJMkt, v.17, n.5, 759-770.

Melo, M. T., Nickel, S., \& Saldanha-da-Gama, F. (2009). Facility location and supply chain management - A review. European Journal of Operational Research, 196(2), 401-412. https://doi.org/10.1016/j.ejor.2008.05.007

Michener, H. A., Delamater, J. D., \& Myers, D. J. (2005). Psicologia social. São Paulo: Thomson.

Moeller, S. (2010). Characteristics of services - a new approach uncovers their value. Journal of Services Marketing, 24(5), 359-368. https://doi.org/10.1108/08876041011060468

Morgan, R. M., \& Hunt, S. D. (1994). The Commitment-Trust Theory of Relationship Marketing. Journal of Marketing, 58(3), 20. https://doi.org/10.2307/1252308

Munaier, C. G. e S., \& da Costa, C. R. M. (2021). Influence of usage and contractual binds on customer retention in Continually Delivered Services: Evidence from the Physical Fitness Business. RISUS - Journal on Innovation and Sustainability, 12, 101-114. https://doi.org/10.23925/2179-3565.2021v12i2p101-114

O'Cass, A., \& Carlson, J. (2012). An e-retailing assessment of perceived website-service innovativeness: Implications for website quality evaluations, trust, loyalty and word of mouth. Australasian Marketing Journal, 20(1), 28-36.

https://doi.org/10.1016/j.ausmj.2011.10.012

Ravald, A., \& Grönroos, C. (1996). The value concept and relationship marketing. European Journal of Marketing, 30(2), 19-30. https://doi.org/10.1108/03090569610106626

Rosendahl, Z. (2005). Território E Territorialidade : Uma Perspectiva. Anais Do X Encontro de Geógrafos Da América Latina, 12928-12942.

Shimp, T. A., \& Sharma, S. (1987). Consumer ethnocentrism: Construction and validation of the CETSCALE. Journal of Marketing Research, 24(3), 280-289.

Shulga, L. V., Busser, J. A., Bai, B., \& Kim, H. (2021). The Reciprocal Role of Trust in Customer Value Co-Creation. Journal of Hospitality and Tourism Research, 45(4), 672696. https://doi.org/10.1177/1096348020967068

Siemieniako, D., Kubacki, K., Glińska, E., \& Krot, K. (2011). National and regional ethnocentrism: a case study of beer consumers in Poland. British Food Journal, 113(3), 404-418. 
Song, H. J., Wang, J. H., \& Han, H. (2019). Effect of image, satisfaction, trust, love, and respect on loyalty formation for name-brand coffee shops. International Journal of Hospitality Management, 79(December), 50-59. https://doi.org/10.1016/j.ijhm.2018.12.011

Southworth, S. S. (2019). U.S. Consumers' Perception of Asian Brands' Cultural Authenticity and Its Impact on Perceived Quality, Trust, and Patronage Intention. Journal of International Consumer Marketing, 31(4), 287-301. https://doi.org/10.1080/08961530.2018.1544528

Strehlau, V. I., Ponchio, M. C., \& Loebel, E. (2012). Uma avaliação da escala de etnocentrismo do consumidor (CETSCALE): Indícios do Brasil. BBR-Brazilian Business Review, 9(4), 108-132.

Vivek, S. D., Beatty, S. E., \& Morgan, R. M. (2014). CUSTOMER ENGAGEMENT: EXPLORING CUSTOMER RELATIONSHIPS BEYOND PURCHASE. 16(3), 259-270. https://doi.org/10.2753/MTP

Velloso, M. (1993). A brasilidade verde-amarela: Nacionalismo e regionalismo paulista. Revista Estudos Históricos, 6(11), 89-112.

Warnaby, G. (2018). Taking a territorological perspective on place branding? Cities, 80, 6466. https://doi.org/10.1016/j.cities.2018.06.002

Zhang, J., \& Bloemer, J. M. M. (2008). The impact of value congruence on consumer-service brand relationships. Journal of Service Research, 11(2), 161-178. https://doi.org/10.1177/1094670508322561

Zhao, Q., Chen, C. Der, Wang, J. L., \& Chen, P. C. (2017). Determinants of backers' funding intention in crowdfunding: Social exchange theory and regulatory focus. Telematics and Informatics, 34(1), 370-384. https://doi.org/10.1016/j.tele.2016.06.006 


\title{
CONSTRUINDO CONFIANÇA NA MARCA AO ESCOLHER O LOCAL CERTO: QUANDO A LOCALIZAÇÃO DA SEDE DO NEGÓCIO INFLUENCIA A CONFIANÇA DOS CLIENTES EM UMA MARCA
}

\author{
Christian Gomes-e-Souza Munaier \\ Universidade de São Paulo - USP. \\ São Paulo, SP - Brasil \\ munaier@usp.br
}

Rodolfo Rodrigues Rocha Universidade de São Paulo - USP. São Paulo, SP - Brasil. rodolfo.rocha@usp

\section{Jerônimo Henrique Portes \\ Universidade Presbiteriana Mackenzie - UPM \\ São Paulo, SP-Brasil \\ jeronimo.portes@bol.com.br}

Objetivo: Investigamos a influência da localização da sede do negócio de uma empresa de serviços sobre a confiança dos clientes na marca.

Método: Uma pesquisa online foi realizada com os clientes da marca Les Mills, resultando em 138 respostas válidas. Foram utilizadas técnicas estatísticas multivariadas para análise dos dados coletados.

Principais resultados: A confiança dos clientes em uma marca de serviços com uma única sede regional em um país varia dependendo da região geográfica do país. Clientes no mesmo estado onde a sede regional única de uma empresa de serviços está localizada confiam mais na marca de serviços do que clientes de outros estados da mesma região geográfica. Clientes de áreas geográficas com culturas abertas mostram níveis mais altos de confiança geral na marca do que clientes de regiões geográficas com culturas fechadas.

Contribuição teórica/metodológica: Contribuímos para a literatura de branding mostrando a influência da localização na confiança na marca. Quanto à teoria da escolha de localização, contribuímos adicionando a confiança na marca como mais uma consequência de tal escolha. Nossa principal contribuição metodológica é a validação da escala de confiança na marca de Delgado-Ballester (2004) no contexto dos serviços.

Relevância/originalidade: Os achados relativos à escolha do local e à confiança na marca têm implicações teóricas e práticas. Por um lado, reunimos dois conceitos aparentemente não relacionados. Por outro, aplicamos tais conceitos a um contexto real de mercado.

Implicações gerenciais: Ao perceber que a localização de uma sede empresarial influencia a confiança dos clientes na marca, argumentamos que a escolha do local é um processo complexo que as empresas devem gerenciar cuidadosamente.

Palavras-chave: Escolha de localização. Confiança na marca. Diferenças regionais.

\section{Como citar}

American Psychological Association (APA)

Munaier, C. G. e S., Rocha, R. R., \& Portes, J. H. (2022, jan./mar.). Construindo confiança na marca ao escolher o local certo: quando a localização da sede do negócio influencia a confiança dos clientes em uma marca. Revista Brasileira de Marketing - ReMarK, 21(Num. Esp.), 91-113. https://doi.org/10.5585/remark.v20i1.20386. 


\section{Introdução}

Escolher a localização de um negócio é uma decisão não trivial que as empresas têm que enfrentar, pois envolve um conjunto complexo de opções (Clouse et al., 2020). Os custos econômicos (por exemplo, mão-de-obra, imobiliário e energia) são as questões elementares que as empresas consideram ao lidar com tal decisão (Melo et al., 2009). No entanto, elementos não econômicos desempenham um papel significativo nas decisões de seleção de locais de negócios (Lunnan et al., 2019). Tais características vão desde qualidade de vida e moradia - com foco nos funcionários (Ebert \& Adam Jr, 1977), fatores sociais e culturais - características da cidade, estado e país (MacCarthy \& Atthirawong, 2003).

É essencial que cidades, estados e países atraiam empresas (Anholt, 2010), pois envolve benefícios de longo prazo que favorecem a imagem do local (Clouse et al., 2019). Combinar interesses comerciais com as características do lugar é uma situação desafiadora que pode beneficiar ambos os lados (Belderbos et al., 2017). As características de uma empresa são moldadas pela cultura da região ou do país em que foi fundada (Khamitov et al., 2009). Quando se trata de empresas e marcas multinacionais, também são impactadas pelas culturas das regiões e países em que estabelecem sua sede regional (Belderbos et al., 2017).

Assumir que diferentes regiões possuem culturas distintas implica reconhecer que os clientes também têm características específicas dependendo de onde moram (Jayne, 2006). A confiança dos clientes em uma marca impactada por uma cultura é uma das características que vêm sendo estudadas por pesquisadores do comportamento do consumidor (Southworth, 2019). A confiança na marca é um aspecto crítico que os clientes consideram ao avaliar alternativas em um processo de decisão de compra (Song et al., 2019). Assim, é um elemento central para as empresas no que diz respeito ao branding e marketing de relacionamento (Morgan \& Hunt, 1994). Uma empresa que fornece bens ou serviços de consumo também pode impactar a congruência entre os valores da marca e dos consumidores (Kaufmann et al., 2016; Zhang \& Bloemer, 2008), tornando a confiança na marca um fator ainda mais dinâmico, em constante mudança, a ser considerado.

No contexto dos serviços, a avaliação dos clientes sobre o risco percebido é mais significativa quando comparada ao contexto dos bens de consumo devido ao alto nível de atributos de credibilidade envolvidos (Shulga et al., 2021). Nessas situações, a confiança na marca é vista como expectativa dos clientes sobre as mensagens de intenção e segurança promovidas pelas empresas (Delgado-Ballester, 2004; Vivek, et al., 2012). Assim, o poder da 
marca torna-se uma vantagem competitiva para as empresas que valem a pena investir dinheiro e esforço (Abimbola, 2001; An et al., 2019; Foroudi, 2019).

Estudos interculturais no comportamento do consumidor geralmente envolvem culturas distintas (Chan et al., 2016), comparando países ocidentais e orientais ou contrastando regiões pobres e ricas. Não foi possível identificar a confiança na marca nos estudos de literatura comparando tal construção em diferentes áreas do mesmo país. Em um país continental como o Brasil, tais diferenças culturais entre as regiões são mais complexas e não refletem a segmentação geográfica utilizada pelos profissionais de marketing (Alfinito et al., 2019). Apesar de sua importância, estudos que mostram o impacto da localização do negócio no comportamento do cliente também estão surgindo na literatura (Belderbos et al., 2017). Finalmente, características específicas do relacionamento cliente-marca em relação à confiança na marca precisam de uma investigação mais aprofundada (Zhang \& Bloemer, 2008).

Com o objetivo de preencher tais lacunas na literatura, os dois objetivos deste estudo são: primeiro, investigamos a influência da localização do negócio na confiança na marca dos clientes. Tal investigação é realizada por meio da análise de clientes de uma marca global de serviços (Les Mills) com sua subsidiária localizada em São Paulo desde o início das operações brasileiras e comparando as diferentes regiões brasileiras. Nosso segundo objetivo é verificar a aplicabilidade da escala de confiança na marca de mercadorias, proposta por Delgado-Ballester (2004) e validada no contexto brasileiro por Bastos et al. (2015) no contexto das marcas de serviços.

Assim, este estudo contribui tanto para a literatura de escolha de localização quanto para a prática, discutindo aspectos culturais envolvidos em tal contexto e revelando as consequências dessa decisão. Os resultados deste artigo mostram uma diferença estatística na confiança na marca dos clientes em relação ao estado de São Paulo (região onde está localizada a sede da empresa) e diferentes regiões brasileiras (por exemplo, São Paulo tem média superior à média da região Sudeste sem São Paulo). Além disso, contribuímos tanto para a literatura de branding quanto para a prática, analisando o conceito de confiança na marca no contexto dos serviços e mostrando as especificidades de tal abordagem. Este manuscrito é organizado da seguinte forma: em um primeiro momento, o referencial teórico e as hipóteses são apresentados. Em seguida, são apresentados os métodos e os resultados tratados quantitativamente de uma escala previamente validada. Por fim, são apresentadas discussões sobre resultados, limitações e sugestões para novas pesquisas. 


\section{Desenvolvimento teórico e hipóteses}

\subsection{Teoria das trocas sociais e confiança na marca}

Desde que Homans (1958) propôs o conceito de trocas sociais (como aprovação, confiança ou prestígio) como um comportamento humano comparável às trocas comerciais, onde o indivíduo busca obter resultados mutuamente gratificantes nessas trocas, pesquisadores têm procurado analisar as possibilidades de sua aplicação em campos variados. Tais estudos proporcionaram avanços na literatura social da Teoria das Trocas Sociais (Social Exchange Theory, ou SET) (Cropanzano \& Mitchell, 2005). De acordo com essa proposta, a SET pode explicar o processo cognitivo decorrente da análise de custo/benefício nas relações sociais. Durante as interações sociais, os diversos comportamentos sociais dos indivíduos são tipos de mercadorias a serem negociadas. Se os ganhos dos indivíduos forem mais significativos do que o custo da interação, eles continuarão a interagir, versus quando o custo for maior, o indivíduo cessará a interação (Zhao et al., 2017).

Confiança é uma intenção, uma atitude de se ver de forma vulnerável às ações do outro que ocorre quando se conclui que a outra parte tem princípios e valores, reúne competências ou habilidades, e expressa o desejo de fazer o bem para quem confia (Barreto et al., 2015). À luz da SET, tais características, inicialmente, atributos das relações humanas, foram levadas às relações comerciais e têm sido uma área intensa de pesquisa para marketing (Abimbola, 2001; An et al., 2019; Delgado-Ballester, 2004; Foroudi, 2019; Kaufmann et al., 2016; Shulga et al., 2021; Song et al., 2019; Vivek et al., 2012; Zhang \& Bloemer, 2008).

A confiança é um dos elementos mais poderosos para uma marca, pois contribui para um relacionamento comercial mais duradouro com os clientes (Berry, 1995). Consistência, competência, honestidade, responsabilidade e cooperação são algumas das características que podem refletir na confiança dos consumidores em uma marca, rumo a relacionamentos duradouros (Baptista et al., 2011). Ao construir confiança e demonstrar comprometimento, uma marca de sucesso pode criar laços emocionais com seus clientes (D'Angelo et al., 2006). Para as marcas das empresas de serviços, a interação entre o cliente e o funcionário que presta o serviço também interfere e determina a confiança do cliente na marca (Guardani et al., 2013). Afinal, os benefícios da empresa quando os clientes confiam em sua marca são notórios, pois o relacionamento vai além de transações simples (Ravald \& Grönroos, 1996). A confiança na marca pode aumentar a lealdade dos clientes e favorecer o boca-a-boca positivo (word-ofmouth, ou WOM) (Broeckelmann \& Groeppel-Klein 2008; O'Cass \& Carlson, 2012) . 


\subsection{Escolha de localização e confiança na marca}

As empresas de bens de consumo escolheram suas fábricas e instalações com base em fatores facilmente mensuráveis, incluindo custos logísticos, custos de energia e incentivos fiscais (Clouse et al., 2020; Melo et al., 2009). Para uma empresa de serviços, as decisões de localização envolvem fatores menos fáceis de medir ou julgar, como disponibilidade de mãode-obra qualificada, qualidade de vida e cultura local (Clouse et al., 2020; Ebert \& Adam Jr, 1977). Quando se trata da escolha da localização de uma sede regional, a conectividade da cidade é a característica mais importante que uma empresa procura (Belderbos et al., 2017).

Com base na literatura da reputação do país, Mariutti (2017) lançou luz sobre a importância de gerenciar a reputação como um aspecto crítico para alcançar a prosperidade sustentável. Bell (2016) reforça tal importância e vai além propondo a conexão entre reputação do lugar e reputação corporativa para avançar ambos os campos de estudo. A literatura sobre branding é mostrada para apoiar a teoria e as práticas gerenciais sobre reputação (Bell, 2016; Mariutti, 2017), que revela que a confiança na marca é um elemento a ser conectado à reputação em sua ampla perspectiva.

Devido à característica da inseparabilidade dos serviços, as marcas de serviços devem entender profundamente os perfis de seus clientes (Moeller, 2010). Diferentes regiões geográficas têm culturas diferentes; portanto, clientes de áreas geográficas distintas possuem características específicas, mesmo que morem no mesmo país (Jayne, 2006). Como a confiança na marca é um aspecto crítico tanto para clientes quanto para marcas (Song et al., 2019), as empresas de serviços devem avaliar as características dos clientes de diferentes áreas geográficas para entender suas especificidades (Kaufmann et al., 2016; Zhang \& Bloemer, 2008). O primeiro passo para esse entendimento é verificar se a confiança na marca dos clientes varia dependendo da região geográfica. Assim, propomos o seguinte:

H1a $_{1}$ A confiança dos clientes em uma marca de serviços com uma sede única em um país varia dependendo da região geográfica do país.

Valores, crenças e senso de pertencimento são elementos presentes no processo de construção de confiança entre os próprios indivíduos e entre empresas e consumidores (Kegler \& Fossá, 2010; Michener et al., 2005). A congruência entre os valores dos clientes e das marcas é determinante para a construção da confiança na marca (Kaufmann et al., 2016; Zhang \& 
Bloemer, 2008), representando um desafio para empresas de sede única com suas marcas presentes em diferentes regiões.

Território e territorialidade são conceitos-chave de geografia para além do espaço físico e de dominação (Rosendahl, 2005). A perspectiva territorológica adquiriu múltiplas aplicações em branding, desde a marca-lugar até a seleção de locais (Warnaby, 2018). Em relação à territorialidade, há uma relação simbólica entre cultura e espaço, reforçada pelos indivíduos do grupo e experiências coletivas sobre o local onde vivem (Rosendahl, 2005). Tais laços podem até determinar a confiança interpessoal (Inglehart, 1999).

Além disso, o etnocentrismo é um conceito sociológico que a literatura de comportamento do consumidor adotou para comparar consumidores de diferentes países, mas que também pode ser usado para comparações estreitas (Fernández-Ferrín \& Bande-Vilela, 2013). Tal conceito pode ser caracterizado como a tendência das pessoas de identificar seu grupo como superior aos outros, reconhecendo seus grupos como o centro do universo (Michener et al., 2005). No Brasil, manifestações de bairrismo também são discutidas em termos de paroquialismo ou localismo (de Sousa Júnior et al., 2019; Lopes, 2009). Assim, como as características culturais de uma marca e de um cliente refletem as especificidades da cultura em que estão inseridos (Khamitov et al., 2019), e esse etnocentrismo faz com que os clientes tenham mais confiança em marcas mais próximas de seu grupo (Shimp \& Sharma, 1987), propomos que:

H1b: Clientes no mesmo Estado onde a sede única de uma empresa de serviços está localizada confiam mais na marca de serviços do que clientes de outros estados da mesma região geográfica.

\subsection{Perspectivas regionais e culturais em confiança na marca}

Consumidores de países geograficamente distantes com culturas opostas podem mostrar comportamentos semelhantes em relação à confiança em marcas locais. Em 1987, o estudo de Shimp e Sharma indicou que os consumidores americanos confiam em mais marcas americanas do que em outros países. Siemieniako et al. (2011) obtiveram resultados semelhantes em um contexto completamente diferente. Uma análise de nível regional descobriu que os consumidores poloneses preferem marcas de suas regiões porque se sentem moralmente obrigados a consumir marcas locais. 
No contexto brasileiro, diversos estudos apontam para a tendência oposta; consumidores preferem e confiam em marcas de outros países do que marcas do Brasil (Klein et al., 2006). No entanto, em uma perspectiva mais estreita, os consumidores da cidade de São Paulo mostram ter comportamentos mais etnocêntricos em relação às marcas do que consumidores de outras capitais brasileiras (Strehlau et al., 2012). Em relação à confiança em geral, uma série de estudos no contexto brasileiro indicam forte presença de paroquialismo ou localismo em alguns estados como São Paulo (Velloso, 1993), Pernambuco e Rio Grande do Sul (de Sousa Júnior et al., 2019). Tais achados sugerem que esses estados têm uma cultura mais fechada. São Paulo também faz parte da região onde os consumidores confiam menos em empresas e marcas em geral, ou seja, no Sudeste (ACSP, 2018).

Enquanto o regionalismo evoca sentimentos que reforçam amplos laços sociais e culturais, paroquialismo ou localismo são ideias que fortalecerão características locais específicas (Freyre, 1996). Assim, é possível sugerir que a confiança na marca está mais próxima das características locais do que aspectos sociais e culturais mais amplos. Tal categorização é reforçada quando analisados os achados da ACSP (2018) mostrando que os consumidores da região Nordeste brasileira possuem altos níveis de confiança geral e os resultados entregues por de Sousa Júnior et al. (2019), indicando que Pernambuco (estado da região Nordeste) tem características de paroquialismo ou localismo. Consequentemente, propomos:

$\mathbf{H}_{2}$ : Clientes de regiões geográficas com culturas abertas apresentam níveis mais elevados de confiança geral na marca do que clientes de regiões geográficas com culturas fechadas.

\section{Método}

Antes do teste de hipóteses, verificou-se a aplicabilidade da escala de confiança na marca elaborada por Delgado-Ballester (2004), validada no contexto brasileiro por Bastos et al. (2015), agora no contexto dos serviços. Várias características de confiança estão presentes em diferentes escalas propostas para medir a confiança na marca dos consumidores (por exemplo, Delgado-Ballester, 2004; Hernandez \& Mazzon, 2005; Li, 2008). Delgado-Ballester (2004) propôs uma escala de confiança de marca composta por oito variáveis para medir a confiança dos consumidores em uma marca espanhola de bens de consumo. Essa escala foi adaptada ao contexto brasileiro por Bastos et al. (2015), observando a confiança dos consumidores em uma 
marca siderúrgica. Hernandez e Mazzon (2005) propuseram uma escala na qual a confiança é reconhecida como um construto multidimensional que envolve as seis dimensões a seguir: disposicional, calculativa, institucional, baseada em conhecimento, baseada em características, e baseada em identificação. É possível identificar uma sinergia consistente analisando ambas as escalas, uma vez que as dimensões de confiança propostas por Hernandez e Mazzon (2005) também estão presentes nos itens de escala de Delgado-Ballester (2004).

\subsection{Escala}

O trabalho atual parte do modelo de Delgado-Ballester (2004) e Bastos et al. (2015), propondo a mesma escala, no entanto, aplicando-a em outro contexto e segmento. Uma escala tipo Likert de 7 pontos foi utilizada no presente manuscrito, onde 1 era "discordo totalmente" e 7 estava "concordo totalmente" com as declarações do questionário. Os ajustes foram feitos em sua aplicação - substituindo a siderúrgica "Alpha" por uma empresa prestadora de serviços, "Les Mills". Os resultados da confiabilidade da escala ( $\alpha$ de Cronbach $=0,9$ ), confiabilidade composta $(0,89)$, variação média extraída $(\mathrm{AVE}=0,5)$, desvio padrão, análise de colinearidade, cargas externas e estatística $\mathrm{T}$ podem ser observados na seção Resultados (Tabela 2) e que foram validados adequadamente (Hair, Jr. et al., 2009).

\subsection{Seleção de amostras}

A Les Mills (www.lesmills.com) é uma empresa com sede na Nova Zelândia presente em mais de 100 países, oferecendo programas técnicos de ginástica coletiva para milhares de empreendedores e instrutores da indústria do Fitness Business. Para que as academias e clubes forneçam aos seus clientes finais um dos programas Les Mills, empreendedores e instrutores devem ser licenciados e treinados participando de um ou dois dias de workshops Les Mills. As taxas de licença são mensais (academias) ou trimestrais (instrutores), e a falta de pagamento resulta na perda de licença do instrutor/empresa e impedimento de continuar usando os serviços de licenciador.

A natureza do serviço oferecido pela Les Mills foi o motivo pelo qual escolhemos esta marca: modelo de serviços continuamente entregues, onde o serviço é prestado ao cliente repetidamente ao longo do contrato (Briggs et al., 2016; Munaier \& da Costa, 2021). Entendemos que esta é uma relação em que o respondente pode medir todos os itens na escala de confiança na marca. 
De 1997 até a data atual (junho de 2021), a empresa manteve sua sede brasileira em São Paulo/SP. Seu endereço é bem conhecido porque, em inúmeras oportunidades, clientes licenciados de todo o Brasil vão até a sede da empresa para workshops e encontros.

Vale reiterar que todos os respondentes validados neste manuscrito eram clientes ativos da marca no momento da coleta. Foram selecionados os respondentes que responderam a uma pergunta filtro, decisiva para sua sequência ou não na pesquisa proposta: você é um proprietário de academia licenciado Les Mills e/ou um instrutor licenciado Les Mills? O entrevistado que respondeu "não" na pesquisa não seguiu para a etapa seguinte e foi excluído. Foram preenchidos 144 questionários completos. Seguindo os passos de Bastos et al. (2015), a presença de outliers foi verificada, realizando o cálculo da distância Mahalanobis. Os 138 resultados do questionário validados podem ser observados na quarta seção

\subsection{Coleta de dados}

A coleta de dados ocorreu online por meio de um link direto para o questionário hospedado na plataforma Google Forms através do banco de dados de clientes da Les Mills. "As plataformas online forneceram acesso conveniente para amostras de empresas e consumidores, que antes eram difíceis, caras e muitas vezes impossíveis de obter" (Hair et al., 2018, p. 689) .

Foram obtidos 144 respondentes que cumprem os requisitos de serem clientes atuais da Les Mills. Seis foram retirados da análise por serem categorizados como outliers, permanecendo 138 respondentes validados. Dos respondentes, 55,8\% eram do sexo masculino, $76,8 \%$ se identificavam como instrutores licenciados e $23,2 \%$ eram donos de academias licenciadas. 66\% dos respondentes têm entre 24 e 37 anos, 81,9\% têm graduação universitária ou superior, e 41,3\% estão no estado de São Paulo, onde está localizado a sede brasileira da Les Mills.

\subsection{Procedimento de análise de dados}

Foram realizadas análise descritiva dos dados, análise fatorial exploratória (AFE) e análise fatorial confirmatória (AFC) dos itens de escala. A AFE foi realizada utilizando-se o método de componentes principais com rotação Varimax. Ambos os softwares IBM SPSS v.22 e SmartPLS v.2.0 foram usados. Verificamos o alfa do Cronbach $(\alpha \geq 0,7)$, a variância média extraída $(\mathrm{AVE} \geq 0,5)$ e a confiabilidade composta $(\mathrm{CC} \geq 0,7)$ como pressupostos mínimos para 
sua aceitabilidade (Hair, Jr. et al., 2009). Além disso, o teste de esfericidade de Bartlett (p < 0.001) e o teste Kaiser-Meyer-Olkin (KMO).

As hipóteses, as referências teóricas que as sustentam, as técnicas multivariadas utilizadas para validá-las e os resultados esperados podem ser observados na Figura 1.

\section{Figura 2}

Matriz de Amarração Metodológica

$\begin{array}{cccccc}\text { Estrutura } & \text { Metas de Pesquisa } & \text { H } & \text { Itens } & \text { Técnicas de } & \text { Resultados de pesquisa } \\ \text { Teórica } & & & & \text { Análise } & \text { esperados }\end{array}$

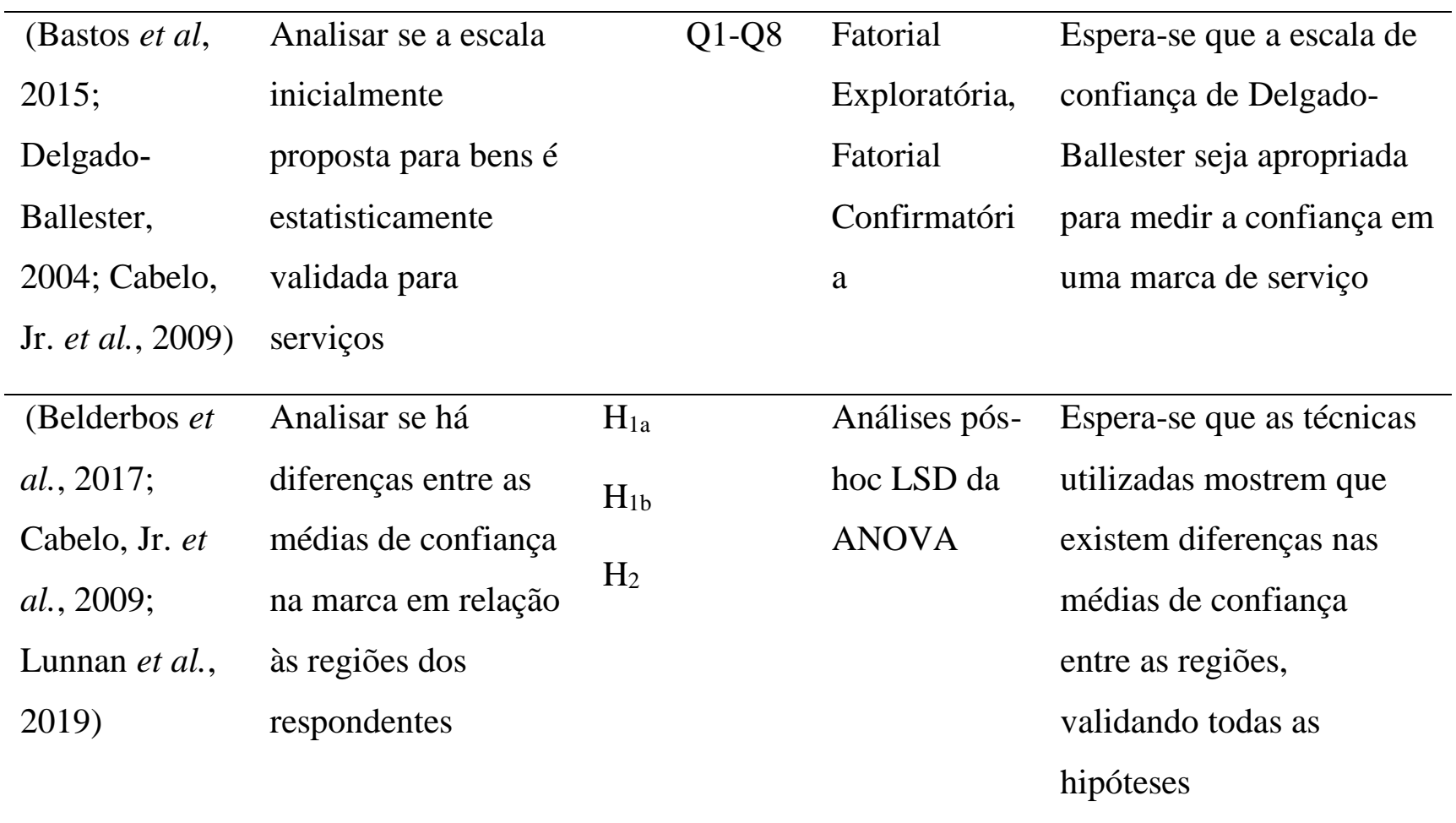

Fonte: Elaborado pelos autores a partir de Mazzon (2018)

\section{Resultados}

Para entender melhor a distribuição dos respondentes e observar se a confiança na marca Les Mills tem uma resposta diferente dependendo da região do indivíduo, criamos uma categorização como mostrado na tabela 1. Os respondentes do Nordeste $(\mathrm{NE}, \mathrm{n}=30)$ foram classificados como grupo 1. Os respondentes de São Paulo (SP, n = 57) foram classificados como grupo 2. Os respondentes de estados do Sudeste sem SP (SE-SP, n =34) foram classificados como grupo 3, e os respondentes do $\mathrm{Sul}(\mathrm{S}, \mathrm{n}=17)$ foram classificados como 
grupo 4. Não foram utilizados respondentes das regiões Norte e Centro-Oeste do Brasil neste manuscrito.

\section{Tabela 3}

\begin{tabular}{l} 
Distribuição dos Respondentes por Grupos \\
\hline Grupo Região Frequência $\%$
\end{tabular}

\begin{tabular}{cccc}
\hline Grupo 1 & NE & 30 & $26,5 \%$ \\
Grupo 2 & SP & 57 & $38,8 \%$ \\
Grupo 3 & SE-SP & 34 & $23,1 \%$ \\
Grupo 4 & S & 17 & $11,6 \%$ \\
\hline & Total & $\mathbf{1 3 8}$ & $\mathbf{1 0 0 \%}$
\end{tabular}

$\overline{\overline{\text { Fonte: Elaborado pelos autores a partir da coleta de dados }}}$

Os respondentes de São Paulo foram separados dos demais estados do Sudeste brasileiro para observar melhor sua atitude, uma vez que, como mencionado acima, a sede brasileira da Les Mills está em São Paulo/SP. É possível observar que quase um terço dos respondentes são do estado onde está localizada a sede da empresa no Brasil.

As médias, desvios padrão, análise de colinearidade, cargas externas e estatísticas T dos 138 respondentes podem ser vistos na Tabela 2, bem como as análises de validade da escala de Confiança. 


\section{Tabela 4}

Análises estatísticas

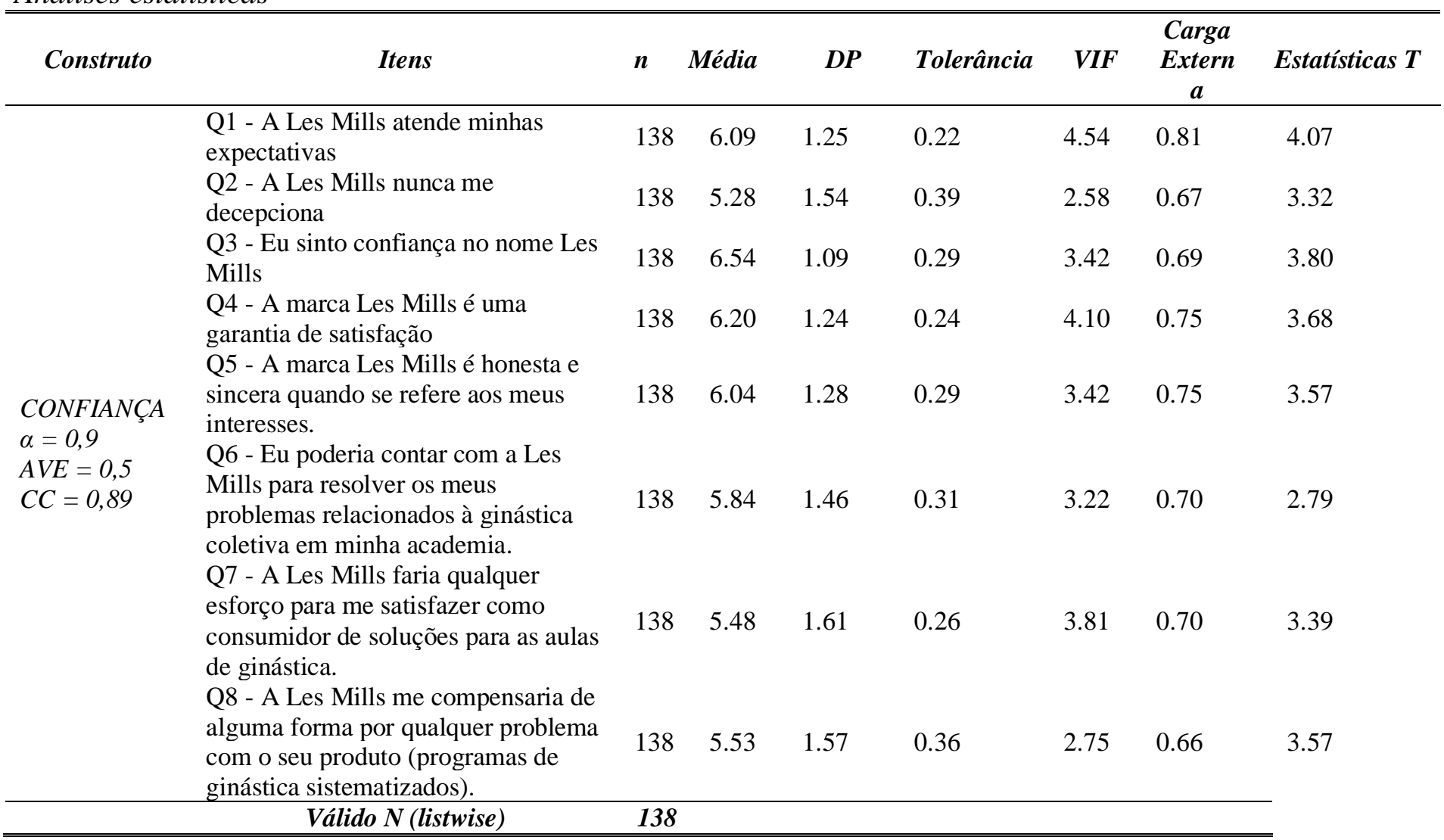

Fonte: Elaborado pelos autores a partir de Delgado-Ballester (2004) e da coleta de dados. As questões foram aplicadas em português, uma vez que os respondentes eram brasileiros (falantes nativos de português).

Como demonstrado na Tabela 2, as oito variáveis formaram um construto validado pelas premissas das análises de confiabilidade (Hair, Jr. et al., 2009). Alfa de Cronbach =0,9, AVE $=0,5$ e Confiabilidade Composta $=0,89$. As variáveis passaram pelo critério multicollinearidade, todas com VIF inferior a 10. Suas cargas externas e a estatística T de cada indicador também confirmam a qualidade da escala.

Foi realizada uma Análise Fatorial Exploratória. O teste de esfericidade de Bartlett foi significativo $(\mathrm{p}<0,00)$, e o teste de Kaiser-Meyer-Olkin $(\mathrm{KMO})$ foi adequado $(0,908)$ para a análise (Hair, Jr. et al., 2009). 71,6\% de todas as variâncias foram explicadas em um único componente principal, reforçando a consistência e confiabilidade da escala e validando-a para as seguintes análises. A média das oito variáveis utilizadas na escala tipo Likert de 7 pontos gerou uma nova variável, "TRUST" $\left(\mathrm{M}_{\mathrm{TRUST}}=5,87 ; \mathrm{SD}=1,17\right)$. A partir daí, todas as análises 
foram realizadas para identificar se há diferença na confiança na marca de serviços, dependendo da região onde o prestador de serviços e o cliente estão localizados.

Executou-se uma ANOVA com os quatro grupos deste manuscrito, buscando identificar diferenças estatisticamente significativas entre os meios de confiança na marca nos grupos.

Entre as premissas da ANOVA está a homogeneidade das amostras. Ao observar os resultados dos 138 respondentes, é possível identificar a homogeneidade (teste de Levene, sig = 0,158). Hair, Jr. et al. (2009) recomendam que "em pequenas amostras de 50 ou menos observações, e especialmente se o tamanho da amostra for inferior a 30, desvios significativos da normalidade podem ter um impacto substancial nos resultados" (p. 83). Como nossa amostra é maior que 30, não é necessária a distribuição normal para a análise atual. O teste de Levene, demonstrando a homogeneidade das amostras, oferecendo a condição necessária para seguir com a análise.

A ANOVA resultou em uma diferença estatisticamente significativa entre a confiança na marca e as regiões: FTRUST $(3.134)=3,924 ; p=0,01$. Este resultado confirma $\mathbf{h}_{1 \mathbf{a}}$ que a confiança dos clientes em uma marca de serviços com sede única em um país varia dependendo da região geográfica do país.

Para analisar hipóteses $\mathrm{H}_{1 \mathrm{~b}}$ e $\mathrm{H}_{2}$, foi realizado um teste pós-hoc LSD para identificar as diferenças na média de confiança na marca entre os grupos regionais. O teste pós-hoc LSD é observado na Tabela 3. Observa-se que não há diferença estatística entre as médias de NE e SP $(\operatorname{sig}=1)$, bem como não há diferença entre as regiões brasileiras SE-SP e S $(\operatorname{sig}=0,776)$. No entanto, há diferenças entre NE e SP para SE-SP e S.

\section{Tabela 3}

Teste pós-Hoc LSD: Confiança na Marca e Regiões Brasileiras

\begin{tabular}{|c|c|c|c|c|c|c|}
\hline \multirow[b]{2}{*}{ (I) REGIÃO } & \multirow[b]{2}{*}{ (J) REGIÃO } & \multirow{2}{*}{$\begin{array}{c}\text { Diferença média } \\
\text { (I-J) }\end{array}$} & \multirow[b]{2}{*}{ Std. Error } & \multirow[b]{2}{*}{ Sig. } & \multicolumn{2}{|c|}{ Intervalo de confiança de $95 \%$} \\
\hline & & & & & Limite Inferior & Limite Superior \\
\hline \multirow[t]{3}{*}{$\mathrm{NE}$} & SP & .00000 & .25487 & 1.000 & -.5041 & .5041 \\
\hline & SE-SP & $.71324^{*}$ & .28304 & .013 & .1534 & 1.2730 \\
\hline & $\mathrm{S}$ & .61765 & .34303 & .074 & -.0608 & 1.2961 \\
\hline \multirow[t]{3}{*}{$\overline{\mathrm{SP}}$} & $\mathrm{NE}$ & .00000 & .25487 & 1.000 & -.5041 & .5041 \\
\hline & SE-SP & $.71324^{*}$ & .24485 & .004 & .2290 & 1.1975 \\
\hline & $\mathrm{S}$ & $.61765^{*}$ & .31226 & .050 & .0000 & 1.2352 \\
\hline \multirow[t]{3}{*}{$\overline{\mathrm{SE}-\mathrm{SP}}$} & $\underline{\mathrm{NE}}$ & $-.71324^{*}$ & .28304 & .013 & -1.2730 & -.1534 \\
\hline & SP & $-.71324^{*}$ & .24485 & .004 & -1.1975 & -.2290 \\
\hline & S & -.09559 & .33565 & .776 & -.7594 & .5683 \\
\hline \multirow[t]{3}{*}{$\bar{S}$} & $\mathrm{NE}$ & -.61765 & .34303 & .074 & -1.2961 & .0608 \\
\hline & SP & $-.61765^{*}$ & .31226 & .050 & -1.2352 & .0000 \\
\hline & SE-SP & .09559 & .33565 & .776 & -.5683 & .7594 \\
\hline
\end{tabular}

*. A diferença média é significativa no nível de 0,05 . 
Fonte: Elaborado pelos autores da coleta de dados utilizando o software SPSS.

Vale lembrar que São Paulo é o estado onde está localizada a sede brasileira da empresa e que, como observado no teste pós-hoc, a média de confiança dos clientes alcançada é melhor e estatisticamente diferente de outros estados do Sudeste (SE-SP, sig=0,004). Esse resultado confirma que os clientes no mesmo estado em que a sede única de uma empresa de serviços confia mais na marca de serviços do que clientes de outros estados da mesma região geográfica, validando $\mathbf{H}_{1 b}$.

Como suportado neste artigo, há culturas mais abertas à confiança do que outras. No Brasil, de dimensões continentais, tais diferenças culturais também são observadas. A região do NE brasileiro, região mais aberta à confiança, apresenta a maior média, em antagonismo à SE (sem SP, sig=0,013), região reconhecida como mais conservadora. Esse resultado suporta $\mathbf{H}_{2}$, de que clientes de regiões geográficas com culturas abertas mostram níveis mais altos de confiança geral da marca do que clientes de regiões geográficas com culturas fechadas. Além disso, os clientes paulistas, que inicialmente se esperava comportar menos abertamente, como outros clientes do Sudeste e do Sul, têm um comportamento de confiança parecido ao do Nordeste. Observa-se uma representação gráfica na Figura 2.

\section{Figura 2}

Quatro Grupos e Gráfico de Confiança na Marca 


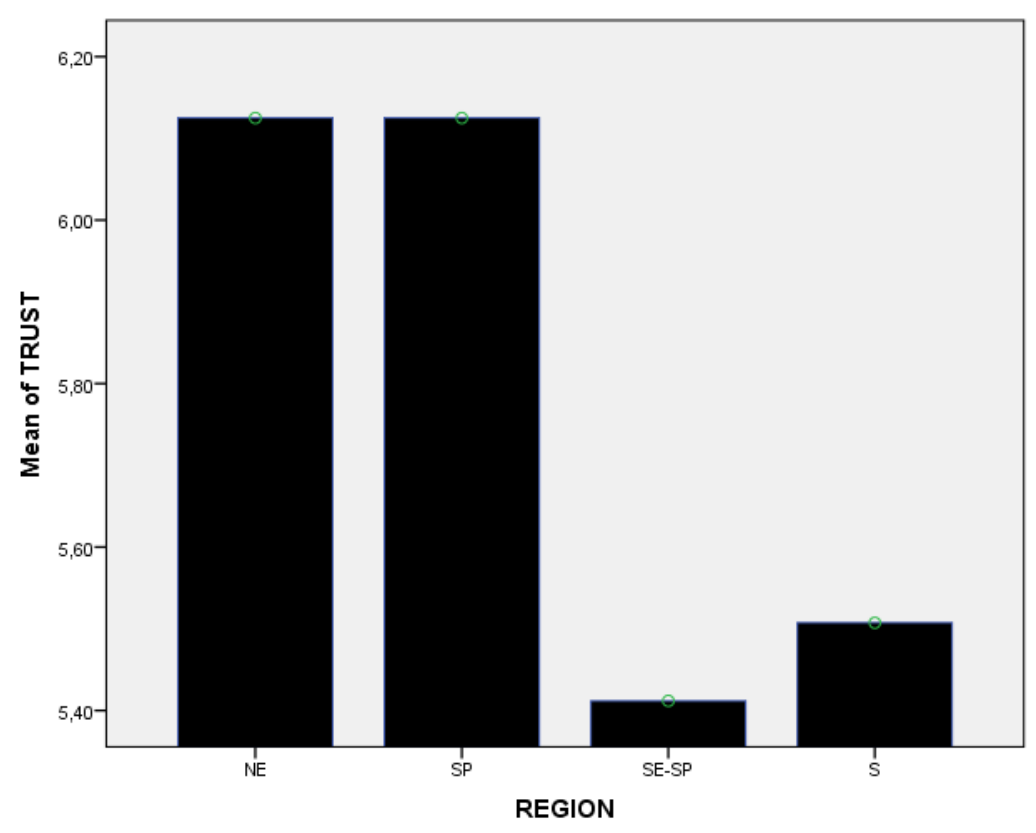

Fonte: Elaborado pelos autores utilizando o software SPSS.

\section{Conclusões}

Nossos achados estão alinhados com a literatura sobre confiança e regionalismo, e as diferenças de confiança nas regiões brasileiras. Conforme identificado pela ACSP (2018), nossos resultados apontam as regiões Sudeste e Sul do Brasil como aquelas com menor confiança na marca quando comparadas, por exemplo, com as regiões nordeste. Os valores congruentes, os laços e o senso de pertencimento entre consumidores e marcas (Inglehart, 1999; Kaufmann et al., 2016; Kegler \& Fossá, 2010; Michener et al., 2005; Zhang \& Bloemer, 2008) também são revelados em nosso estudo um desafio para as empresas, especialmente para aquelas com uma sede única e com suas marcas presentes em diferentes regiões.

À luz da teoria das trocas sociais (SET), a confiança é um atributo humano incorporado pelo marketing das empresas em suas estratégias para ganhar fidelização e engajamento do cliente (Kandampully et al., 2015; Vivek et al., 2014). Nessa perspectiva, este artigo buscou observar a confiança na marca de serviços e as diferenças na confiança na marca em três regiões brasileiras: Nordeste, Sudeste e Sul. Ao fazer isso, buscamos avaliar a diferença entre a confiança na marca de serviços entre seus clientes e a importância de a marca escolher adequadamente sua sede. Afinal, se a confiança é um atributo fundamental para alcançar a fidelização do cliente, e as características da empresa são moldadas pela cultura da região ou 
país em que foi fundada ou na qual uma multinacional estabeleceu sua sede (Belderbos et al., 2017; Khamitov et al., 2009; Lunnan et al., 2019), este artigo contribui tanto para a literatura quanto para as práticas gerenciais.

Estudos anteriores contribuíram para a confiança nas relações de lealdade (Cropanzano \& Mitchell, 2005; Homans, 1958; O'Cass \& Carlson, 2012). A confiança permite que os clientes baixem sua defesa e tomem riscos mais significativos em seu processo de tomada de decisão (Barreto et al., 2015) . Assim, este estudo avança na literatura sobre confiança de marca e regionalismo. Os resultados obtidos por meio da pesquisa com 138 clientes de uma marca de serviço mostram uma diferença estatisticamente significativa na confiança do consumidor em três regiões brasileiras. Nesse sentido, como identificado anteriormente pela ACSP (2018), a região Sudeste é a mais desconfiada, em relação ao Sul e Nordeste (a que mais confia).

No entanto, analisando as médias de confiança dos clientes no estado de São Paulo, as médias são superiores às médias dos demais estados do Sudeste, com diferenças estatisticamente significativas. Além disso, suas médias de confiança são quase tão altas quanto as da região Nordeste, sem diferenças estatísticas. A sede brasileira da empresa observada fica em São Paulo. Assim, este artigo propõe um importante acréscimo à literatura sobre o impacto do local onde a marca de serviço coloca sua sede. É possível afirmar que a localização da marca de serviços melhora a relação de confiança dos consumidores naquela microrregião. Além de ter suporte estatístico para essa afirmação, há também suporte teórico, pois a proximidade geográfica e a abertura para resolver dúvidas e descontentamentos decorrentes de experiências ruins, que a sede próxima oferece, aumentam a sensação de segurança do consumidor. A segurança é um dos elementos centrais da confiança.

Além disso, a escala de Delgado-Ballester (2004) se mostrou adequada para medir a confiança na marca também nos serviços, sendo possível analisar a atitude do consumidor B2B em suas oito variáveis de forma estatisticamente consistente.

Finalmente, ao perceber que a localização da sede de uma empresa influencia a confiança na marca dos clientes, argumentamos que a escolha do local é um processo complexo que as empresas devem gerenciar cuidadosamente. A confiança na marca é mais um elemento não econômico que deve desempenhar um papel significativo nas decisões de seleção de locais de negócios. Nossas descobertas estão focadas em uma sede regional da marca multinacional de um serviço. No entanto, como a confiança na marca mostrou-se fortemente influenciada pela localização da sede, esperamos que o impacto das escolhas de localização na confiança na marca em outros contextos replicaria nossos resultados. 


\subsection{Implicações gerenciais}

Em primeiro lugar, é essencial prestar homenagem à marca analisada. Com uma média acima de 5 em uma escala tipo Likert de 7 pontos em confiança na marca, a empresa pesquisada tem um alto índice de confiança ( $\mathrm{M}_{\mathrm{TR} U S T}=5,87 ; \mathrm{SD}=1,17$ ). Esse resultado pode ser observado em diferentes intensidades nos quatro grupos estudados, mas em todos eles, com desempenho considerado adequado.

Uma das contribuições deste artigo para as decisões gerenciais foca na perspectiva de necessidades do cliente, claramente no Brasil: o sentimento de proximidade que a marca de serviço precisa para despertar em seu cliente. Embora a decisão de sua sede regional seja levada em conta diversos elementos, desde os estratégicos até os pessoais dos empreendedores, este artigo identifica que a proximidade pode trazer resultados em termos de confiança contrários ao que seriam esperados em uma determinada região. Assim, ter representantes ou postos avançados em diferentes regiões do país pode aumentar a relação de confiança do cliente com a marca. Valerá a pena identificar se, nessa determinada região, existem profissionais com as habilidades necessárias para representar a marca. Se esses profissionais forem identificados e contratados, tê-los representando os valores e a cultura da empresa naquela região pode dar aos clientes locais uma sensação de maior proximidade, que "há um de nós" na empresa para mediar as demandas dos clientes locais.

Outra contribuição prática deste artigo é validar a escala para analisar a confiança em marcas de serviços, que pode ser utilizada pelos gestores de marcas de empresas de serviços, ampliando suas ferramentas de pesquisa. Com apenas oito variáveis, as empresas verificarão o grau de confiança de seus clientes e o analisarão em números absolutos e de forma regionalizada, independentemente de sua área de cobertura. É possível avaliar a confiança na marca em termos regionais ou nacional, como feito nesta pesquisa. Seja em todo o estado ou mesmo municipal, a escala irá avaliar a confiança dos clientes em microrregiões e buscará interferir e melhorar cada uma dessas áreas.

Se a sede da empresa determina uma vantagem local na construção da confiança na marca, as estratégias para aumentá-la e expandi-la estão nas mãos de seus gestores. Tais práticas têm o potencial de influenciar positivamente a reputação das empresas, como sinalizado por Bell (2016) e Mariutti (2017).

\subsection{Limitações e sugestões para pesquisas futuras}


Essa limitação da pesquisa começa com a teoria do apoio, que ainda está muito aquém do necessário para mergulhar mais adequadamente no assunto. Daí, também, a importância deste artigo avançar na teoria. Outra limitação foi o tamanho da amostra. Apesar de compor os dez respondentes por item, o ideal seria ter uma amostra equilibrada das cinco regiões brasileiras, o que é uma limitação e uma sugestão para novas pesquisas. Além do levantamento dos estados, se o respondente é da capital do estado ou do interior poderia ser analisado, podendo haver diferenças entre eles.

Como a confiança na marca não é percebida apenas pelos clientes, mas por vários tipos de stakeholders, as escolhas de localização poderiam ser analisadas em clusters de redes interorganizacionais (Cunha, Passador \& Passador, 2011). Tal abordagem aprofundaria a compreensão dos impactos da escolha do local na confiança na marca. Além disso, redes regionais e urbanas (Beck \& Storopoli, 2021) também são lentes potenciais a serem exploradas por futuras pesquisas.

Outra sugestão para novas pesquisas nesse sentido é analisar escalas concorrentes, utilizando esta e Hernandez e Mazzon (2005), por exemplo, para verificar diferenças e semelhanças nos resultados. Além disso, pode-se verificar variáveis de controle, mediação ou moderação, como o tempo como cliente. Assim, poderiam ser aplicadas técnicas de mediação e moderação.

Por fim, vale ressaltar também a natureza pontual da confiança do consumidor, uma vez que a confiança do consumidor é um termômetro do momento, que pode ser mudado à luz das mudanças econômicas, políticas, sociais e tecnológicas. Assim, poderia ser considerada a limitação de outro artigo e uma sugestão de pesquisa futura (e constante) para sua atualização.

\section{Referências}

Abimbola, T. (2001). Branding as a Competitive Strategy for Demand Management in SMEs. Journal of Research in Marketing and Entrepreneurship, 3(2), 97-106. https://doi.org/10.1108/14715200180001480

ACSP - Associação Comercial de São Paulo. (2018). Índice Nacional de Confiança do Consumidor. Recuperado de http://mkt.acspservicos.com.br/digital/imprensa/ACSP_INC_Onda161_agosto2018.pdf. Acesso em 14 de março de 2021.

Alfinito, S., Assumpção, M., Torres, C. V., \& de Aragão, B. S. (2019). Is geographic segmentation suitable for marketing studies? An investigation applied to Brazil. Revista Brasileira de Marketing, 18(2), 243-267. https://doi.org/10.5585/remark.v18i2.3882 
An, J., Ngo, L. V., Chylinski, M., \& Tran, Q. (2019). Customer advocates with a generous heart. Journal of Services Marketing, 33(2), 192-205. https://doi.org/10.1108/JSM-04-20180120

Anholt, S. (2010). Definitions of place branding-working towards a resolution. Place Branding and Public Diplomacy, 6(1), 1-10. https://doi.org/10.1057/pb.2010.3

Baptista, P. de P., Silva, W. V. da, \& Goss, L. P. (2011). Qualidade percebida e seus impactos sobre a satisfação, confiança e lealdade: um estudo com varejistas eletrônicos de serviços de download gratuito. Revista de Ciências Da Administração, 249-277. https://doi.org/10.5007/2175-8077.2011v13n30p249

Barreto, I. F., Crescitelli, E., \& Figueiredo, J. C. B. (2015). Relationship Marketing results: proposition of a cognitive mapping model. Revista Brasileira de Gestao de Negocios, 17(58), 1371-1389. https://doi.org/10.7819/rbgn.v17i58.2692

Bastos, D. H., Moura, L. R. C., \& Christino, J. M. M. (2015). Mensuração, teste e validação da confiança na marca. Revista Capital Científico - Eletrônica, 13(2). https://doi.org/10.5935/2177-4153.20150010

Beck, D., \& Storopoli, J. (2021). Cities through the lens of Stakeholder Theory: A literature review. Cities, 118, 103377. https://doi.org/10.1016/j.cities.2021.103377

Belderbos, R., Du, H. S., \& Goerzen, A. (2017). Global Cities, Connectivity, and the Location Choice of MNC Regional Headquarters. Journal of Management Studies, 54(8), 1271-1302. https://doi.org/10.1111/joms.12290

Bell, F. (2016). Looking beyond place branding: the emergence of place reputation. Journal of Place Management and Development, 9(3), 247-254. https://doi.org/10.1108/JPMD-082016-0055

Berry, L. L. (1995). Relationship marketing of services-growing interest, emerging perspectives. Journal of the Academy of marketing science, 23(4), 236-245

Bochenek, M., \& Pomaskow, J. (2014). The use of the brand to build a competitive advantage of contemporary companies. Ekonomia i Prawo. Economics and Law, 13(2), 285-296.

Briggs, E., Landry, T. D., \& Daugherty, P. J. (2016). A framework of satisfaction for continually delivered business services. Journal of Business and Industrial Marketing, 31(1), 112-122. https://doi.org/10.1108/JBIM-06-2014-0125

Broeckelmann, P., \& Groeppel-Klein, A. (2008). Usage of mobile price comparison sites at the point of sale and its influence on consumers' shopping behaviour. The International Review of Retail, Distribution and Consumer Research, 18(2), 149-166.

Chan, F. F. Y., Petrovici, D., \& Lowe, B. (2016). Antecedents of product placement effectiveness across cultures. International Marketing Review, 33(1), 5-24. https://doi.org/10.1108/IMR-07-2014-0249 
Clouse, C., Dixit, A., \& Turken, N. (2020). The role of place image for business site selection: a research framework, propositions, and a case study. Place Branding and Public Diplomacy, 16(2), 174-186. https://doi.org/10.1057/s41254-019-00144-4

Cropanzano, R., \& Mitchell, M. S. (2005). Social Exchange Theory: An Interdisciplinary Review. Journal of Management, 31(6), 874-900. https://doi.org/10.1177/0149206305279602

Cunha, J. A. C. D., Passador, J. L., \& Passador, C. S. (2011). Recomendações e apontamentos para categorizações em pesquisas sobre redes interorganizacionais. Cadernos EBAPE.BR, 9, 505-529. https://doi.org/10.1590/S1679-39512011000600005

D'Angelo, A. C., Schneider, H., \& Laran, J. A. (2006). Marketing de relacionamento junto a consumidores finais: um estudo exploratório com grandes empresas brasileiras. Revista de Administração Contemporânea, 10(1), 73-93.

Delgado-Ballester, E. (2004). Applicability of a brand trust scale across product categories. European Journal of Marketing, 38(5/6), 573-592. https://doi.org/10.1108/03090560410529222

de Sousa Júnior, J. H., Santos, W. S., \& da Rocha, R. A. (2019). A influência do bairrismo no comportamento de consumo em Pernambuco e no Rio Grande do Sul. $13^{\circ}$ Congresso Latino-Americano de Varejo e Consumo.

Ebert, R. J., \& Adam Jr, E. E. (1977). The Human Factor in Facilities Location Planning. Business Horizons, 20(6), 35-42.

Fernández-Ferrín, P., \& Bande-Vilela, B. (2013). Regional ethnocentrism: Antecedents, consequences, and moderating effects. Food Quality and Preference, 30(2), 299-308. https://doi.org/10.1016/j.foodqual.2013.06.011

Flores Filho, E. G. J., \& Ribeiro, R. C. (2012). Racionalidade limitada do consumidor e assimetria de informação. Economic Analysis of Law Review, 3(1), 109-121.

Foroudi, P. (2019). Influence of brand signature, brand awareness, brand attitude, brand reputation on hotel industry's brand performance. International Journal of Hospitality Management, 76(May 2018), 271-285. https://doi.org/10.1016/j.ijhm.2018.05.016

Freyre, G. (1996). Manifesto regionalista. In FUNDAJ (7ª). Ed. Massangana.

Guardani, F., Teixeira, M. L. M., Bido, D. D. S., \& Mazzon, J. A. (2013). The relationship between values, organizational practices and customers trust in the services sector. Production, 23(4), 806-817

Hair, Jr., J. F. H., Black, W. C., Babin, B. J., Anderson, R. E., \& Tatham, R. L. (2009). Análise Multivariada de Dados (6 ed). Artmed.

Hair, J. F., Harrison, D. E., \& Risher, J. J. (2018). Marketing research in the 21st century: Opportunities and challenges. In Revista Brasileira de Marketing (Vol. 17, Issue 5). https://doi.org/10.5585/bjm.v17i5.4173 
Hernandez, J., \& Mazzon, J. (2005). Trust development in e-commerce and store choice: model and intial test. ENANPAD 2005. Encontro Nacional de Pós-graduação em Administração, Brasília.

Homans, G. C. (1958). Social Behavior as Exchange. American Journal of Sociology, 63(6), 597-606. https://www.jstor.org/stable/2772990

Inglehart, R. (1999). Trust, well-being and democracy. Democracy and trust, 88, 88-120.

Kahneman, D., \& Tversky, A. (1979). Prospect theory: An analysis of decision under risk. Econometrica: Journal of the Econometric Society, 47(2), 263-292.

Kaufmann, H. R., Loureiro, S. M. C., \& Manarioti, A. (2016). Exploring behavioural branding, brand love and brand co-creation. Journal of Product and Brand Management, 25(6), 516-526. https://doi.org/10.1108/JPBM-06-2015-0919

Kegler, B., \& Fossá, M. I. T. (2010). “ORGULHO GAÚCHO”: DE ELEMENTO IDENTITÁRIO REGIONAL À ESTRATÉGIA PUBLICITÁRIA. Razón y Palabra, 15(74), $1-26$.

Khamitov, M., Wang, X. (Shane), \& Thomson, M. (2009). ACRoss space and time: How cultural and institutional differences explain consumer-brand relationships' differential effects on brand loyalty. AP - Asia-Pacific Advances in Consumer Research, 36, 11-12. http://www.acrwebsite.org/volumes/1700304/volumes/ap12/AP-12 [copyright]

Lopes, R. H. (2009). "Cada brasileiro receba a parcella do insulto que lhe cabe": Regionalismo, separatismo e bairrismo no processo de mobilização cearense durante a Guerra de 1932. Revista Especialidades, 2(1), 1-18.

Lunnan, R., Tomassen, S., Andersson, U., \& Benito, G. R. G. (2019). Dealing with headquarters in the multinational corporation: a subsidiary perspective on organizing costs. Journal of Organization Design, 8(1). https://doi.org/10.1186/s41469-019-0052-y

MacCarthy, B. L., \& Atthirawong, W. (2003). Factors affecting location decisions in international operations - A Delphi study. International Journal of Operations and Production Management, 23(7-8), 794-818. https://doi.org/10.1108/01443570310481568

Mariutti, F. G. (2017). The placement of country reputation towards place management. Journal of Place Management and Development, 10(3), 240-253. https://doi.org/10.1108/JPMD-10-2016-0067

Mazzon, J. A. (2018). Uso da matriz de Amarração Metodológica em Marketing. Brazilian Journal of Marketing - BJMkt, v.17, n.5, 759-770.

Melo, M. T., Nickel, S., \& Saldanha-da-Gama, F. (2009). Facility location and supply chain management - A review. European Journal of Operational Research, 196(2), 401-412. https://doi.org/10.1016/j.ejor.2008.05.007

Michener, H. A., Delamater, J. D., \& Myers, D. J. (2005). Psicologia social. São Paulo: 
Thomson.

Moeller, S. (2010). Characteristics of services - a new approach uncovers their value. Journal of Services Marketing, 24(5), 359-368. https://doi.org/10.1108/08876041011060468

Morgan, R. M., \& Hunt, S. D. (1994). The Commitment-Trust Theory of Relationship Marketing. Journal of Marketing, 58(3), 20. https://doi.org/10.2307/1252308

Munaier, C. G. e S., \& da Costa, C. R. M. (2021). Influence of usage and contractual binds on customer retention in Continually Delivered Services: Evidence from the Physical Fitness Business. RISUS - Journal on Innovation and Sustainability, 12, 101-114. https://doi.org/10.23925/2179-3565.2021v12i2p101-114

O'Cass, A., \& Carlson, J. (2012). An e-retailing assessment of perceived website-service innovativeness: Implications for website quality evaluations, trust, loyalty and word of mouth. Australasian Marketing Journal, 20(1), 28-36.

https://doi.org/10.1016/j.ausmj.2011.10.012

Ravald, A., \& Grönroos, C. (1996). The value concept and relationship marketing. European Journal of Marketing, 30(2), 19-30. https://doi.org/10.1108/03090569610106626

Rosendahl, Z. (2005). Território E Territorialidade: Uma Perspectiva. Anais Do X Encontro de Geógrafos Da América Latina, 12928-12942.

Shimp, T. A., \& Sharma, S. (1987). Consumer ethnocentrism: Construction and validation of the CETSCALE. Journal of Marketing Research, 24(3), 280-289.

Shulga, L. V., Busser, J. A., Bai, B., \& Kim, H. (2021). The Reciprocal Role of Trust in Customer Value Co-Creation. Journal of Hospitality and Tourism Research, 45(4), 672696. https://doi.org/10.1177/1096348020967068

Siemieniako, D., Kubacki, K., Glińska, E., \& Krot, K. (2011). National and regional ethnocentrism: a case study of beer consumers in Poland. British Food Journal, 113(3), 404-418.

Song, H. J., Wang, J. H., \& Han, H. (2019). Effect of image, satisfaction, trust, love, and respect on loyalty formation for name-brand coffee shops. International Journal of Hospitality Management, 79(December), 50-59. https://doi.org/10.1016/j.ijhm.2018.12.011

Southworth, S. S. (2019). U.S. Consumers' Perception of Asian Brands' Cultural Authenticity and Its Impact on Perceived Quality, Trust, and Patronage Intention. Journal of International Consumer Marketing, 31(4), 287-301. https://doi.org/10.1080/08961530.2018.1544528

Strehlau, V. I., Ponchio, M. C., \& Loebel, E. (2012). Uma avaliação da escala de etnocentrismo do consumidor (CETSCALE): Indícios do Brasil. BBR-Brazilian Business Review, 9(4), 108-132.

Vivek, S. D., Beatty, S. E., \& Morgan, R. M. (2014). CUSTOMER ENGAGEMENT: 
EXPLORING CUSTOMER RELATIONSHIPS BEYOND PURCHASE. 16(3), 259-270. https://doi.org/10.2753/MTP

Velloso, M. (1993). A brasilidade verde-amarela: Nacionalismo e regionalismo paulista. Revista Estudos Históricos, 6(11), 89-112.

Warnaby, G. (2018). Taking a territorological perspective on place branding? Cities, 80, 6466. https://doi.org/10.1016/j.cities.2018.06.002

Zhang, J., \& Bloemer, J. M. M. (2008). The impact of value congruence on consumer-service brand relationships. Journal of Service Research, 11(2), 161-178.

https://doi.org/10.1177/1094670508322561

Zhao, Q., Chen, C. Der, Wang, J. L., \& Chen, P. C. (2017). Determinants of backers' funding intention in crowdfunding: Social exchange theory and regulatory focus. Telematics and Informatics, 34(1), 370-384. https://doi.org/10.1016/j.tele.2016.06.006 